\title{
Margaret Mead and Derek Freeman: Bibliography of a controversy
}

\author{
by
}

John Roberts Laurie

submitted to the Department of Library and Information Studies,

Victoria University of Wellington,

in partial fulfilment of the requirements for the degree of

Master of Library and Information Studies

15th February, 1998

h

AS741

VUW

A55

L385

$\mathrm{M}$ 


\section{INTRODUCTION}

Derek Freeman's 1983 attack on Margaret Mead's classic Samoan ethnography, Coming of age in Samoa, aroused an unprecedented level of interest in the world of anthropology and among the educated public. That interest continues, over a decade later, with the publication of a play based on the lives of Mead and Freeman, and a major new book. The issues, of the nature of humankind and human society, are central to our understanding of humanity and the establishment of good relationships among the peoples of the world. Mead's Coming of age in Samoa is probably the best known anthropological work ever written and has had a major influence on popular perceptions of Western society and indigenous cultures. Freeman's claims, that Mead deliberately exaggerated the differences between Samoa and the West in order to advance a particular political agenda, that all human cultures are rooted in a particular biological human nature which is an inheritance from our primate ancestors, and that the study of cultures should have reference to this universal set of human proclivities and tendencies (which different cultural structures and institutions have evolved to guide and restrain) has serious implications for an anthropology which has generally abandoned attempts to explain similarities to concentrate on differences. At this theoretical level there has been much debate about Boas' commitment to physical anthropology. The critical point is surely that a commitment to cultural determinism does not preclude an interest in biological variables. It is a question of which direction of influence is studied. One of Boas' main contributions appears to have been to attempt to prove that even such apparently biological variables as head shape are determined by environmental rather than inherited factors. ${ }^{1}$ Unlike the early years of the 20 th century, it is now the believers in cultural determinism who are insisting on dramatic differences between different societies and those proposing a greater role for biological factors who are arguing the fundamental unity of the human species.

\section{Coverage and selection criteria}

This is a selective bibliography. It is not an exhaustive list of all material relating to the controversy. The

\footnotetext{
${ }^{1}$ Boas, F. 1912. Changes in bodily form of descendants of immigrants. 61st U.S. Congress, Senate Document 208, cited in Murray, Stephen O. Problematic asppects of Freeman's account of Boasian culture. Current Anthropology 31(4): 406.
} 
main aim is to cover major scholarly contributions up to the end of $1996^{2}$ It also includes a representative sample of Samoan ethnography, concentrating on items written by those who have contributed most significantly to the controversy. Biographical works have not been covered although they may have light to cast on Mead's motivations; nor has background material on theoretical issues in anthropological methodology and understandings of culture and evolution. Many reviews without any substantial original contribution to make have also been omitted and some relatively minor items by New Zealanders have been incorporated.

\section{Audience}

Annotations concentrate on summarising the arguments and the general aim has been to produce a guide for academics and students from the social sciences (and interested members of the public), which will enable an overview of the literature and guide its readers to key works for initial consideration, material focusing on particular strands in the debate, and items which are related to each other. A general idea of the various points at issue in the controversy can also be gained from reading the bibliography as an introductory guide

\section{Arrangement}

Items are arranged in chronological order by year of first publication. This has the advantage of providing an overall view of the course of events and allows the grouping of items which relate to each other. Items from the special sections in American Anthropologist, Pacific Studies and Canberra Anthropology are together and most of those reviewing or specifically referring to an earlier contribution are placed immediately after that contribution. Items outside these categories are in alphabetical order within their year.

\footnotetext{
${ }^{2} \mathrm{~A}$ few items have proved impossible to obtain within the time frames of the assignment. Particularly regretted are the 1988 film about the controversy which includes interviews with Freeman and Fa'apua'a Fa'amu. (Heimans, Frank. 1988. Margaret Mead and Samoa. Film. Sydney: Cinetel Productions.) and Holmes' original thesis (Holmes, Lowell D. 1957. The restudy of Manua culture: A problem in methodology. Ph.D. diss., Northwestern University, Evanston, Illinois.)
} 
references supplied by Holmes (1987) (Item 47) and James E.Cote (1994) (Item 70) are also worthy of attention.

\section{Acknowledgements}

I would like to acknowledge the help of Interloans staff at the University of Auckland Library, James Traue, my supervisor, for his useful comments and prompt replies to my questions, and Felicity Stewart for her help with proof-reading.

John Laurie

New Zealand and Pacific Collection

University of Auckland

1998 


\section{Indexing}

There is a unitary author/title/subject index at the end of the sequence. Journal articles are indexed by journal title not by the title of individual articles. Authors are highlighted in bold type and titles of books and journals are in italics.

\section{Notable contributions}

The bibliography includes four books which consider the various issues at length - in addition to Freeman's original refutation (Item 12). These provide an obvious place for those unaquainted with the controversy to begin. Lowell D. Holmes' Quest for the real Samoa (Item 47), is a strong defence of Mead as is James Cote's Adolescent storm and stress (Item 70). Martin Orans' Not even wrong (Item 72) and The Samoa reader (Item 61) are biased towards Freeman's views. The Samoa reader contains excerpts from Mead and Freeman's books and other contributions to the debate and also background material on Samoan culture and cultural determinism. Martin Orans' extensive survey of Mead's fieldnotes makes his work unique and he also has the advantage of the last word at this stage. The reader is also referred to the three journals publishing special sections on the controversy. The American Anthropologist (Items 17-20), Canberra Anthropology (Items 21-28) and Pacific Studies (Items 29-32). The last two include long replies by Derek Freeman.

\section{Further reading}

The material covered represents only a fraction of the literature generated by the controversy. Many newspapers and popular magazines have featured articles which are not listed here. Early contributions of this kind, to 1983, are included in a select bibliography (237 items) in Canberra Anthropology (Item 23). I have found no similar lists of more recent material. All the books listed in the previous section and most of the journal articles listed have substantial bibliographies or lists of bibliographical references. Readers are directed to Stephen O. Murray (1991) (Item 65), and Derek Freeman (1990) (Item 64), for bibliographic coverage of the role of cultural determinism in the history of anthropology in particular. The long lists of 


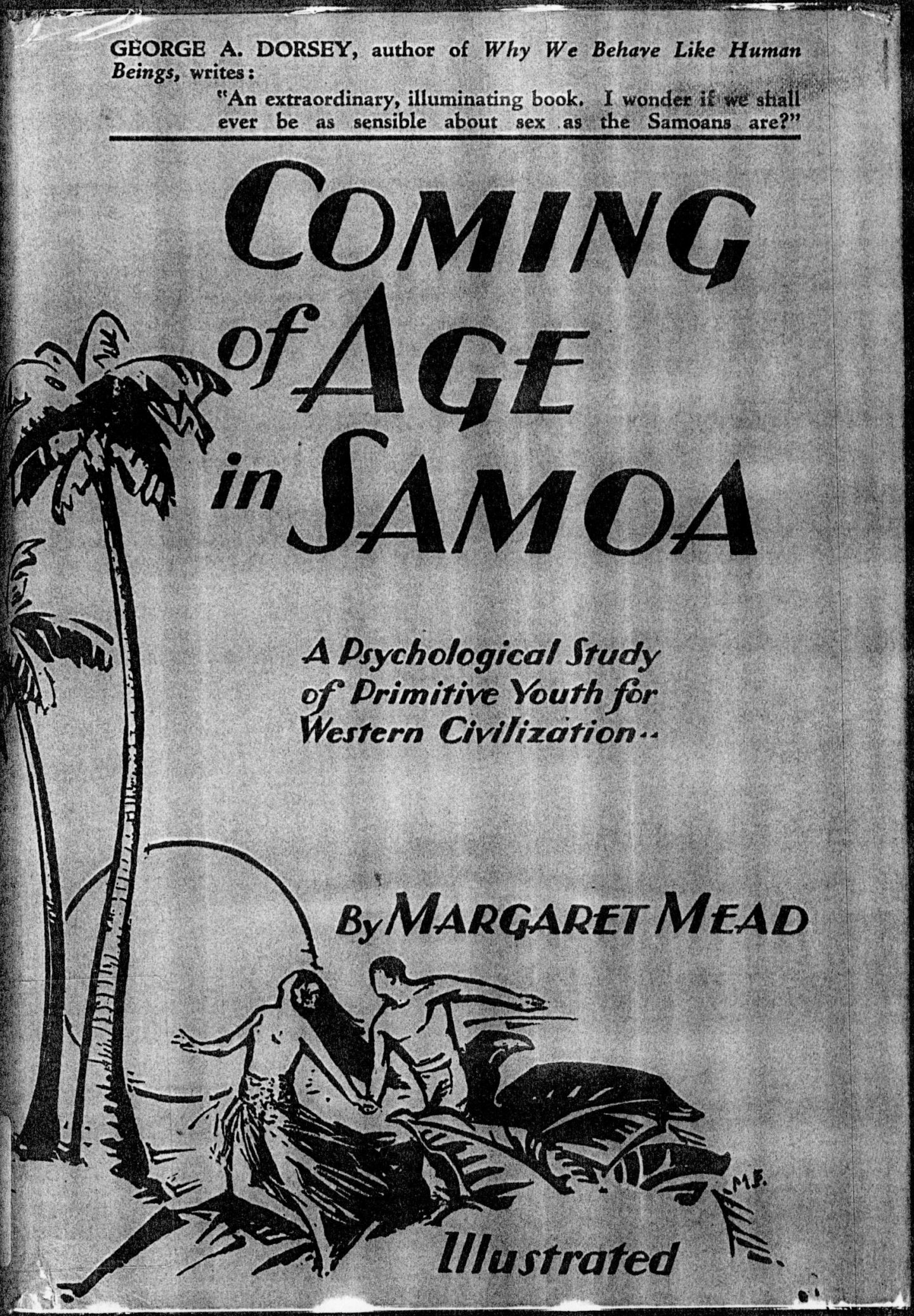


1. Mead, Margaret. [1928] 1943. Coming of age in Samoa: A study of adolescence and sex in primitive societies. Harmondsworth: Penguin.

First published in 1928 under the title Coming of age in Samoa: A psychological study of primitive youth for Western civilisation, this book had gone through 5 printings by 1931. Penguin published it in 1943 and reprinted in 1954 and 1961. It could be said to be one of the most influential books of the twentieth century and many of its assertions about the nature of humankind and the failings of civilization became received wisdom in the Western world.

The 23 year-old Mead was sent to Samoa by her mentor, Franz Boas, to test the hypothesis that the stress associated with adolescence in Western countries was the result of maladaptive cultural factors rather than some underlying problem of human nature faced by all societies. The book is the result of several months work on the island of Ta'u in American Samoa with a group of about 50 girls aged from 10 to 18 . These girls are pictured at many points as individuals with detailed descriptions of their individual circumstances, experieces and characters. Sexuality is a strong focus with an entire chapter on "Formal sex relations" in a culture with "no neurotic pictures, no frigidity, no impotence...and the capacity for intercourse only once in a night is counted as senility" (p.124). In general Mead paints an idyllic picture of a stress-free life in a tropical paradise of sexual adventure, where "lovers slip home from trysts beneath the palm trees or in the shadow of beached canoes" (p.19). However, one chapter in the appendix sketches the lives of two girls who might be called delinquents and another small group who aspire to education and a life outside the constraints of village life. There are further chapters on the household and the community, maturity and old age, and the role of dance in Samoan society.

"Adolescence represented no period of crisis or stress, but was instead an orderly developing of a set of slowly maturing interests and activities" (p.129). Neuroses caused by premature exposure to childbirth, intercourse and death or being the only child in a "tiny ingrown biological family" are mitigated in Samoa by the familiarity which comes from living in close association with a wider number of people. Mead castigates the lack of sex education in the West and the "fateful policy of sparing children a knowledge of the dreadful truth" about death.

The last quarter of the book is devoted to "Our educational problems in the light of Samoan contrasts" and suggestions for improvements. Problems of adolescents in America are attributed to the range of life choices available, conflicting moral standards in society, and the nuclear family and the level of ignorance about sex and life crises it engenders. 
Solutions are proposed in a more tolerant attitude to adolescent "sex experimentation" and education for choice. 240pp. No references.

2. Lowie, Robert H. 1929. Review of Coming of age in Samoa: A psychological study of primitive youth for Western civilisation, by Margaret Mead. American Anthropologist 31(3): 532-534.

Praises Mead's work as a solid contribution to ethnography, which illustrates "a new method of study bound to find followers and yield an even richer harvest". Finds her picture of "Polynesian free love" convincing and mentions her vivid pictures of child life and the doubt her account throws on the universality of the individual family. However, characterises as "pedagogical sermonising" her thesis that "the sexually uninhibited Samoan adolescent is thereby freed from the stress and strain characteristic of our adolescents, hence these disturbances are not rooted in original nature, but in the repressive agencies of our society". Notes discrepancies between the picture presented in the main text and Mead's claim in an appendix (which he quotes at length) that Samoan society was stricter in the past. Considers that evidence of sexual licence in an acculturated society, subject to the "blighting contact of Western civilisation", is on a par with stories about middle-Westerners in Greenwich Village.

No references. 
3. Mead, Margaret. 1930. Social organization of Manua. Honolulu: Bernice P. Bishop Museum. Bulletin (Bernice P. Bishop Museum); 76.

Begins with notes on some aspects of the author's fieldwork in 1925. The bulk of the book focuses on social structure and rank, kinship and family relationships and ceremonies and rituals. Ends with a section about the Tui Manu'a and the seven villages of Manu'a. Brief chapters entitled 'Birth', 'Childhood', 'Adolescence' and 'Courtship, marriage and maturity', the latter set in the past tense, add little to the material published in Coming of age in Samoa in this area. A chapter on religion describes traditional Samoan society. Includes a discussion on discrepancies between the ideal and the real (p.5), identifying this area as one of the author's major research concerns, and a description of cultural evolution in terms of individual temperament (p.86). Has been extensively mined by many of the protagonists in the controversy for quotes to support their arguments.

218 pp. Bibliography, pp.215-218.

4. Winston, Ellen. 1934. The alleged lack of mental diseases among primitive groups. American Anthropologist 36(2): 234-238.

Throws doubt on the widespread assumption that mental disorders and psychoses are more prevalent in Western societies. Cites several anecdotal accounts of insanity from ethnographical studies of tribal societies and uses data collected by Mead in Manu'a and Tutuila in an attempt to quantify and compare rates of mental illness in the United States and Samoa. Compensates for the different age structures of the two populations.

Bibliographical footnotes. 
5. Holmes, Lowell D. 1957. Ta'u : Stability and change in a Samoan village. Parts land 2. Journal of the Polynesian Society 66(3): 301-338, 66(4): 398-435.

Largely taken from the first part of the authors dissertation ${ }^{1}$ and based on his five months in Ta'u with his wife and daughter in 1954. Covers most aspects of Samoan culture and society under the chapter headings 'Material culture and economics', 'Social organisation', 'Political organisation', 'Religion', 'The life-cycle' and 'Cultural stability and cultural change'. Admits most of his data came from three English-speaking school teachers with supplementary interviews in halting Samoan. Supports Mead's analysis at various points including the lack of strong parent/child relationships, the prevalence of adoption, the smooth transition from adolescence to adulthood and relative sexual freedom for the young. "Promiscuity is condemned by the church but winked at by the family" (p.411). Criticises Mead for conflating accounts of contemporary society with attempted reconstructions of a "traditional" past and virtually ignoring the role of formal education in the life of her girls. Notes in passing that attempts to establish a Catholic presence on the island in 1948 led to a house being stoned and preparations for an armed affray, that punishment of children is often severe, that moetotolo risks bodily injury and general ostracism if discovered, that the discovery of adultery usually results in violence and that eloping couples are often subject to beatings. Represents the taupou institution, tattooing and the pastor's school as being in abeyance, but supports the thesis of Samoan cultural conservatism. Emphasises the isolation of Ta'u and the lack of outside influences.

Footnotes and 17 references.

${ }^{1}$ Holmes, Lowell D. 1957. The restudy of Manu'a culture: A problem in methodology. Ph.D. diss., Northwestern University 
6. Mead, Margaret. 1961. Review of Ta'u: Stability and change in a Samoan village, by Lowell D. Holmes. American Anthropologist 63(4): 428-429.

Casts doubt on the value of restudies unless to document social change. Criticises Holmes' methodology, citation of sources, lack of system, vagueness and failure to analyse kinship structures. Notes Samoan conservatism in the retention of customs already disappearing in 1925. Refutes Holmes' criticism that she ignored current social realities in an attempt to reconstruct the past.

No references. 
7. Mead, Margaret. [1972] 1975. Blackberry winter: My earliest years. New York: Pocket Book.

Mead's autiobiography covering the years from her birth to the outbreak of the Second World War. Includes 53 pages on her years at university and nineteen pages on her fieldwork in Samoa. Essential to an understanding of the personal attitudes and preconceptions which informed Mead's view of Samoa and Samoan culture - and has been heavily mined by later commentators. Records an upper middle class background of privilege, education and moral fervour for "progressive" causes, including the belief that changes in attitudes and the removal of injustice and prejudice would usher in a better world for all.

Describes the writer's unhappiness at her rejection by the sorority-fraternity circles which dominated her first college in the mid-west and later years of contentment and intellectual engagement at Barnard College, New York, where she came into contact with Boas and Ruth Benedict and absorbed their teachings on society and culture. The Samoan section is briefer with notes on her experiences and the practicalities of fieldwork in a foreign country and language. A large part of the chapter is devoted to her understanding of "primitive" cultures.

The second half of the book covers her later work in Niugini and Bali and her attempts to synthesize a general theory of culture and temperament from her experiences. Mentions several occasions of disagreement with husbands/fellow anthropologists about the nature of various societies. "It had not yet occurred to us that the difference in our experiences - Reo's with Dobu and mine with Samoa - had nearly as much to do with us as individuals, as it had to do with the nature of the cultures we studied." (p.212).

$337 \mathrm{pp}$. Index 
8. Mead, Margaret. 1977. Letters from the field, 1925-1975. New York: Harper \& Row.

Excerpts of selected letters from the period 1925-1975, with a general introduction by Margaret Mead which ponders both on the implications of the inclusion of the observer within the circle of relevance for ethnographic description, and, more generally, on the difficulties of portraying another culture. Describes the development of an ethnographic methodology of "participant observation". Discusses her own experiences of fieldwork and later developments. The volume is presented as a record of the early development of theory and practice in anthropology. Shorter notes introduce each chapter.

Includes 37 pages of letters from Samoa. Backgrounds her work on Ta'u and introduces personal responses and contemporaneous events missing from the ethnographies. Has been studied and quoted at length by both detractors and defenders. Mentions Fa'apua'a Fa'amu several times.

xxii, 343 pp. Index and bibliography 
9. Schoeffel, Penelope. 1979. Daughters of Sina: A study of gender, status and power in Western Samoa. Ph.D. diss., Australian National University.

An ethnography based on 18 months residence in a Samoan village. The author, married to an untitled Samoan man, had four children with her during her research. Generally focuses on the roles and status of women from a feminist perspective, and depicts a dualism in female status - respected and valued as co-descendants, subordinate as wives. States that her observations were at a variance with those of Mead and that she will "add my voice to [Freeman's] regarding regarding role strain for Samoan adults" (p.156). Contrasts her findings with those of an earlier study of the same village and postulates a breakdown of community spirit and village unity in the intervening period.

Illustrates chapters on girls and boys, males and females, husbands and wives, sisters and brothers, healers and ghosts, ladies and women with 13 stories about particular events and individuals. These include a banana growing project which ended in recriminations and accusations of misappropriation of funds, a teenage suicide, a man holding up his fingers at a wedding to claim the bride for himself on account of a moetotolo, and an illegitimate pregnancy.

Discusses and analyses the punishment of children, adolescent female rivalries, rape and moetotolo, illegitimacy, adultery and adolescents moving in with other families and critiques Mead's conclusions in these areas. Depicts a society with a double standard of morality "like any other".

No note on references made. 
10. Freeman, Derek. 1981. The anthropology of choice: An ANZAAS presidential address given in Auckland, New Zealand, on 24th January, 1979. Canberra Anthropology 4(1): 82-100.

Traces the course of human evolution from palaeolithic times and contends that culture is formed as a result of an enormous series of free choices made by individuals, and transmitted to succeeding generations by imitation and, after the development of language, by the learning and teaching of linguistically coded information. Emphasises a continuity between genetic and cultural evolution but contends that the second cultural evolutionary system has become dominant over the original genetic one and that this has ended the ability of sociobiological theory to account fully for human evolution. Postulates that "culture is essentially a socially sanctioned accumulation of alternatives that have been selected from the vast range of human possibility" (p.97). Argues that this invalidates the doctrine of cultural relativism, that the unforeseen consequences of past choices may be highly deleterious and anthropology must be prepared to make a critical approach to cultural practices and values. Castigates cultural determist anthropology as a superseded science, noting its tendency to stress the importance of custom, tradition and taboo at the expense of choice and change. Refers to Mead's ethnography in Samoa as an example. Concludes that man is a self-defining animal.

5 references. 
11. Shore, Bradd. 1982. Sala'ilua: A Samoan mystery. New York: Columbus University Press.

Shore's major published ethnography. Reflects the author's conviction that "the other is profoundly different from oneself" (p.xiii). Begins with an account of the murder of one of the two highest ranking chiefs in Sala'ilua village by the son of the other. (Both men were teachers at the local school.) Traces subsequent events including the efforts of other village leaders at various meetings to avoid a family feud and restore peace. Considers special factors in the structure of Sala'ilua village which precipitated the murder. Examines aspects of status and social control in Samoan society more generally, discussing titles and property, fono and fa'alupega, and village law and sanctions. Attempts to elucidate Samoan understandings of institutions and structures by examining Samoan terminology. The second half of the book, headed 'Meanings', considers Samoan concepts of identity, human nature and knowledge, and the individual and society, postulating a context-oriented Samoan self, which is focused on multi-faceted social relationships. Describes Samoan notions of amio and aga which describe behaviour originating in selfish individual desires and behaviour that is socially approved and required. Investigates concepts of causation and motivation, crime, guilt and moral judgement. Develops a dualistic theory of ranked and unranked relationships and examines them in the context of gift exchanges and male/female relationships. Emphasises differences from Western cultural categories. Concludes with a chapter on Samoan dance and a renewed look at the "cultural mystery" that lies behind the original murder. xvii, 338pp., notes, bibliography, pp.321-326, and index. 
12. Freeman, Derek.. [1983] 1996. Margaret Mead and the heretic: The making and unmaking of an anthropological myth. Ringwood, Vic.: Penguin.

This book is a republication of Derek Freeman's Margaret Mead and Samoa: The making and unmaking of an anthropological myth, published in Canberra and New York by the Australian National University Press and Harvard University Press in 1983. A new foreword by the author includes a transcript of the statement made by Fa'apua'a Fa'amu, one of Mead's chief Samoan informants in 1987, detailing the way she and her friends misled Mead.

Sketches a brief history of the development of Boasian cultural determinism in opposition to the dominant eugenicist ideas in the early twentieth century, and the gradual adoption of an extremist cultural determinist position by Kroeber and Lowie after the First World War. Outlines Mead's career in anthropology, her intellectual debt to Ruth Benedict and the circumstances surrounding her 1925 field-trip to Samoa. Summarizes Mead's depiction of Samoan society and surveys Coming of ages's reception in Western intellectual circles from the enthusiastic response of the 1930s to growing doubts in the 1970 s.

The bulk of the book is devoted to a point-by-point refutation of Mead's conclusions about Samoan culture. Freeman draws on his own experiences in Samoa, the writings of other anthropologists, a detailed analysis of various contradictions in Coming of age, and statistical comparisons of crime and deviance in Samoa and various other countries. Various features of Samoan society including rank, aggression, punishment, adolescent delinquence and sexual mores and behaviour are discuussed.

Two final chapters critique the series of false premises which led Mead astray and point the way to "a more scientific anthropological paradigm" incorporating advances in other approaches to the study of human behaviour. Bibliographical references and index. 
13. Barnouw, Victor. 1983. Coming to print on Samoa: Mead and Freeman. The Journal of Psychoanalytic Anthropology 6(4): 425-433.

Summarises the salient features of Mead's ethnographic account and Freeman's refutations. Notes Freeman's failure to cite Ellen Winston's 1934 article on mental health and primitive societies (q.v.). Notes the author's impression on rereading Coming of age that Mead's generalisations are not as egregious as Freeman implies. Attributes this to Mead's "unfortunate tendency to make stronger and broader assertions in later works", and notes that a large proportion of Freeman's quotes come from these. Summarizes Freeman's analysis of the reasons for Mead's errors. Notes conflicting evidence about premarital sexuality and various attempts to reconcile the two pictures.

Considers Freeman's analysis of the development of cultural determinism and expresses scepticism about his picture of Boas as a cultural determinist and the degree of Boas' influence over Mead. Supports the picture of Mead's strong belief in the enormous malleability of human nature, whether derived from Boas or Benedict. Debates the influence of Freudian psychology on Mead and briefly considers some implications of a greater role for biological factors in explaining culture.

Note and 14 references. 
14. Bock, Philip K. 1983. The Samoan puberty blues. Review of Margaret Mead and Samoa, by Derek Freeman. Journal of Anthropological Research 39(3): 336-340.

Finds Freeman's "main substantive criticism" convincing, but suggests few anthropologists will be surprised. Exonerates Freeman from charges of sociobiological extremism but accuses him of overstating the darker side of Samoan culture and of oversimplification regarding Boas' motives and theoretical standpoints. Discusses Freeman's claims about premarital chastity and adolescent crime and violence. Suggests a cumulative table of ages at first conviction would have been a statistically sounder method of comparing adolescent crime. Contends that moetotolo is a very socialised and symbolic form of rape. Is bemused by Freeman's call for a synthesis of biological and cultural anthropology which he believes has already taken place.

12 references.

15. Romanucci-Ross, Lola. 1983. Apollo alone and adrift in Samoa. Reviews in Anthropology 10(3): 85-92.

Summarizes Freeman's contentions. Asserts that phenomenologies must at least in some basic ways converge to validation by consensus and accuses some critics of precipitate denunciation. Notes Mead's fears in 1964, after meeting Freeman in Australia, that he would prove her wrong, and her puzzlement that another researcher could have found so much contrary evidence. Discusses her own work in Mexico where it was three years before she discovered real levels of conflict, violence and mismatch of moral codes in the face of local evasions and assertions to the contrary. Suggests Mead was not the most meticulous researcher and comments on the basic problem-solving orientation of her fieldwork. The auther worked with Mead in Manus.

18 references. 
16. Wendt, Albert. 1983. Three faces of Samoa: Mead's Freeman's and Wendt's. Pacific Islands monthly (April) 10-14, 69

States how the author first came into contact with what he calls Mead's romantic, escapist portrayal of Samoa at an Auckland Training College course in 1958, and, having spent his own teen years in New Zealand, accepted it as valid. Now accuses Mead of arrogance and naivety and failing to rise above stereotypes and preconceptions of "primitive" societies. Praises Freeman's account as the "most important study of us made this century by a non-Samoan" (p.10) and expresses his admiration for a man who has studied Samoa for 40 years, has an easy fluency in the language and has been adopted into a family and granted a matai title. Suggests that he has been able to divulge some of the "secrets" which all societies have, finding Freeman's Samoa "similar to the Samoa I know and have depicted in my fiction." Explores the yearning in industrialised societies (and among some Polynesians) for a South Seas utopia. Blames Mead for failing to return to Samoa to correct the harm she had done. Excuses Freeman's dwelling on a darker side of Samoan society and considers his depiction shows a society with all the emotions, problems, hopes common to humanity. Contends, however, that Freeman exaggerates the purity, strictness and public morality aspect of Samoan culture and downplays the incidence of premarital sex and adultery. Suggests an element of machismo and bravado in Samoan society is reflected in the second-class status Samoan women have always held, and the institutionalisation of moetotolo as a form of rape. Comments ironically on the influence of Mead's book on sexual mores in the United States, stating that there is more free love there than there ever was in Samoa.

No references. 
17. Holmes, Lowell. 1983. A tale of two studies. American Anthropologist 84(4): 929-935. Special Section: Speaking in the Name of the Real: Freeman and Mead on Samoa.

Agrees with Mead that Samoan coming of age was "immensely less stressful and traumatic" than in the West. Comments on the value of restudies in anthropology of which his own of Ta'u was the first. Such studies will show differences because of cultural change and personal and methodological factors, and should be holistic analyses. Notes Mead's belief that they will inevitably be done in the shadow of the original study and will either attempt to confirm or deny its conclusions. Disparages Freeman's claims to superior insight and puts forward his own claims to a matai title which he says he never took seriously. States his own detailed analysis of Mead's material is in his 1957 thesis $^{2}$, not in his published writings. Attributes the differences between Mead's (and his own) and Freeman's findings to cultural change over time, and social disorganisation in the urban areas of Apia and Pago Pago. Notes Freeman offers no comparative information on adolescence in the United States in the 1920s and cites passages from contemporary studies suggesting grief and strife. Questions Freeman's ability, as an elderly white man, to collect accurate statistics on virginity and claims his experiment in removing toddlers from their mothers is methodological nonsense. Suggests psychological tests carried out in Samoa by himself and others show a personality profile more compatible with Mead's characterisation than Freeman's. Gives instances of blatant selective quotation by Freeman and attacks the promotion of the book by the Harvard University Press, saying he is glad his own restudy has remained quietly on the thesis shelf at Northwestern University.

32 references. 
18. Schwartz, Theodore. 1983. Anthropology: A quaint science. American Anthropologist 84(4): 919-929. Special Section: Speaking in the Name of the Real: Freeman and Mead on Samoa.

Calls for a balanced discussion and sees possibilities for reconciling the protagonists' views when a proper assessment can be made. Notes other occasions where a restudy has contradicted a classic ethnography and suggests this shows we must respect the complexity of "primitive" cultures. Notes a general failure to distinguish between a genetic and essentially racial or racist determinism, and a generic biological determinism, and notes that neither Mead nor Freeman seek to explain Samoan culture in terms of peculiarities in the Samoan genetic environment. Notes Mead's facility for dramatic distillation, inconsistencies with Mead's own data, and Freeman's “contrariant bias”. Agrees with Freeman's views on Mead's motivations and preconceptions but can't believe that the girls were able to create and maintain the fantasy foisted on Mead or that Mead deliberately reported falsely. Suggests a time lapse problem with restudies, doubts the accuracy of both sets of figures on virginity and notes ambivalence in Holmes' views about Mead's accuracy.

Praises Mead's work in Manus for the knowledge she was able to gain in six months and the vividness of her descriptions, but notes her resistance to the idea that her informants were heavily involved in a cargo cult and her remark that if Manus turned out to be another cultural shambles, a slum culture, she would not write about it - the world needed a success story. The author worked in Manus with Mead in 1953.

Notes and 17 references. 
19. Shore, Bradd. 1983. Paradox regained: Freeman's "Margaret Mead and Samoa". American Anthropologist 84(4): 935-944. Special Section: Speaking in the Name of the Real: Freeman and Mead on Samoa.

Contends that neither Freeman nor Mead is completely wrong and attempts to reconcile the two versions, claiming that human life is riddled with contradictions, ethnographic accounts are not susceptible to refutation, and Freeman has allowed his obsession with refutation and his fascination with Mead to ruin what could have been a real contribution to Samoan ethnography. Notes, however, long-recognised problems with Mead's picture of Samoan society and suggests that the concept of cultural configuration was instrumental in channelling Mead's observations to conform to a single dominant theme.

Posits a gradual withdrawal of early attachment by parents leading to a diffuseness of affection and argues that Freeman's unsophisticated experiments with infants are not sufficient proof of the opposite. Notes most observers are at odds with Freeman's observations on residential flexibility for adolescents. Believes Freeman's comments on Samoan promiscuity are compelling but notes Mead's essential ambivalence on this issue when read carefully. Considers both authors on rank and deference and suggests a double socialisation in explanation. Notes Mead's attribution of liberalisation in the arenas of politics and sex to Western influences. Points out that the case for culture not nature does not rest on Samoa alone and asks how Freeman would account for the many distinctive differences between Samoa and the United States if not by culture. Notes that Freeman provides little detail about the application of his interactionist paradigm to Samoan culture.

6 references. 
20. Weiner, Annette. 1983. Ethnographic determinism: Samoa and the Margaret Mead controversy. American Anthropologist 84(4): 908-919. Special Section: Speaking in the Name of the Real: Freeman and Mead on Samoa.

Considers Freeman's work "fails in its history, in its ethnography and as a scientific refutation" and is "badly written and deeply destructive" (p.918). Defends Mead's Samoan researches as sophisticated and innovative. Analyses political and social background to Boas' attack on the eugenicists. Notes widespead belief that genetic factors determined criminality, shiftlessness, prostitution and feeblemindedness and the enactment of laws prescribing sterilisation and restricting immigration. Accuses Freeman of distorting Boas' position on biology and culture and notes Boas' work on the head shapes of immigrant populations.

Argues that $\mathrm{Ta}^{\prime} \mathrm{u}$ and Western Samoa are historically and geographically distinct. Suggests a need for caution in relying on the testimony of Samoans and Trobrianders about their own societies, especially when sensitive topics are involved. Suggests Freeman's attacks on Shore should create suspicion. Attacks the source and accuracy of Freeman's figures on virginity. Suggests virginity and defloration ceremonies concerned taupou alone and that presentation of fine mats after elopements implies public recognition of premarital sex in the same way as presentations after deflorations implied public recognition of virginity. Contends that, in 1926, "puritanical Christian sexual morality had not yet pervaded this island" (p.916). Rebuts evidence of Court prosecution of adulterers on the grounds that the real circumstances are unknown and that adultery is different from premarital sex. Suggests that evidence from Malinowski's work in the Trobriands, where premarital intercourse was the rule and adolescence free of stress, would equally have provided Boas with the "negative instance" he sought.

22 references. 
21. Holmes, Lowell D. 1983. On the questioning of as many as six impossible things about Freeman's Samoan study before breakfast. Canberra Anthropology 6(1): 1-15. Special Volume: Fact and Context in Ethnography: The Samoa Controversy.

Asserts the writer's authority as author of a 1954 methodological restudy of Mead's Ta'u. Attacks six of Freeman's unbelievable claims about Boasian determinism and $\mathrm{Ta}^{\prime} u$.

1. That Boas was an absolute cultural determinist: Quotes assessments of Boas to the contrary and notes his studies of biological factors. Stresses the prominence of physical anthropology in the American academic world.

2. That Freeman could not publish his book until now because he did not gain access to certain criminal records on rape and assault in American Samoa until 1981: Notes Freeman's circulation of papers attacking Mead as early as 1968. Attacks validity and reliability of official material in Samoa.

3. That Holmes was so intimidated by Mead's reputation and under the thumb of his Boasian tutor, Melville Herskovitz, that he refrained from attacking Mead and cultural determinism and concentrated instead on an acculturalisation study: States that his critique of Mead's work is in his 1957 thesis $^{3}$ not in the summary in the Journal of the Polynesian Society. Affirms the general reliability of Mead's findings and discusses various points of disagreement, notably on the degree of sexual freedom and degree of competitiveness. Corroborates Mead's conclusion that coming of age was easier in Ta'u in 1925 than in the United States. Lists contributing factors as diffusion of authority and affection, childhood knowedge of life crises, early involvement in adult tasks, flexibility of residence, lack of conflicting choices and clear limits to sanctioned behaviour.

4. That Ta'u is culturally the same as Sa'anapu:

5. That data collected from 1940s to 1981 can be compared with data from 1925 .

6.That Derek Freeman is a serious scientist: Accuses Freeman of seeking evidence to support a preconceived theory, of selective quotation and of lacking objectivity. Contrasts his own commitment (and that of other Boasians) to cultural relativity as a methodological tool. Criticises inflated statements made by Freeman about the importance of his book and his use of data collected by Boasians, such as himself and Mead, to attack Boasian anthropology. Suggests Freeman should have written a proper ethnography.

33 references. 
22. Jarvie, I.C. 1983. Freeman on Mead. Canberra Anthropology 6(1):80-85. Special Volume: Fact and Context in Ethnography: The Samoa Controversy.

Questions the scientific validity of anthropology's aversion to restudies and the premium based on recording as many pre-literate societies as possible "before they disappear". Discusses reasons for the impact caused by Freeman's book and typifies Coming of age in Samoa as part of the "large literature of self-reflection on American society suggesting other societies as models". Finds Freeman's message depressing that Samoan society is "not noticeably less tense, conflict-ridden or productive of unhappiness than our own" (p.83). Suggests the need for an anthropology of anthropologists. Attacks the standard of Mead's fieldwork and supports Freeman's assertion that her statements are both testable and refutable. Affirms Mead's place in the growth of knowledge is secure.

No references.

23. The Samoa controversy: a select bibliography. 1983. Canberra Anthropology 6(1): 86-97. Special Volume: Fact and Context in Ethnography: The Samoa Controversy.

Lists 237 items in alphabetical order. The majority are newspaper articles and reviews. Includes a number of contributions by various Samoan citizens. No annotations. 
24. Schoeffel, Penelope and Malama Meleisea. 1983. Margaret Mead, Derek Freeman and SSamoa: The making, unmaking and remaking of an anthropological myth. Canberra Anthropology 6(1): 58-69. Special Vcolume: Fact and Context in Ethnography: The Samoa Controversy.

Ascribes differences in Mead's and Freeman's accounts to the dualism inherent in Samoan 1 culture and confusion between the realms of actual private behaviour and public socially sanctioned norms. Freerman is accused of a tendency to automatically counter Mead's assertions with contrary observations and facts. If Mead ppresents a picture of the social ideal he presents the actual behaviour and if she describes actual behaviour he asserts the iddeal.

Suggests clandestine love affairs are not uncommon but are severely punished if discoveredd and that female virginity in an ideal aspired to by all families. Describes moetotolo as covering circumstances ranging $t$ from rape to romance. The male will be severely beaten if he is caught, regardless of any compliance on the part of the 2 female. Later he may boast about it to his friends and the girl may be humiliated by gossip. Moetotolo often occurs in aa situation where families are in conflict, or in an attempt to force an elopement.

Attacks Freeman's statistics on female virginity - in particular his reliance on membership obf the Ekalesia as evidence of virginity. Supports Mead's contention of "passive acceptance" by the Church of pre-maritaal sex, but only because the Church cannot act until the matter has become public. Similarly brothers are constrained inn beating their sister for having an affair, because it would be confirming her sexual delinquency in the eyes of the wworld and contributing to the collective dishonour. Supports Mead's findings on adolescent mobility between homes witth several personal examples, but notes that formally such moves should only be a result of arrangements between adults. : .

Contends major social changes between 1925 and the 1960s render much of Freeman's datta suspect. Alludes to major changes in the community studied by Penelope Schoeffel between 1971 and 1976-1982 andd ascribes them to the power vacuum left by the aging of several powerful chiefs. Notes that universal school attendancee has removed the housework labour force from the home and speaks vaguely of other examples of economic, social and c cultural strain.

Ascribes differences in Mead's and Freeman's accounts to different perspectives. Mead's agge gave her informal access to the views and concerns of youth, while Freeman's accession to chiefly rank was a barrieer to such confidences and experiences. Records that Mead's depiction has always been distasteful to Samoans and Frreeman's is congenial to adult 
25. Shankman, Paul. 1983. The Samoan conundrum. Canberra Anthropology 6(1): 38-57. Special Volume: Fact and Context in Ethnography: The Samoan Controversy.

Concedes Freeman's success in "staggering the establishment", eroding Mead's credibility and transforming the image of Samoa, but criticises his imprecision, his overstatement and his failure to prove any of his major contentions. States his criticisms of Mead are not new. Discusses Freeman's account of Mead's preconceptions and gullibility, her residence at the naval dispensary and her fluency in Samoan and defends her competence and accuracy. Quotes Robert Maxwell and Joseph Theroux on the difficulties of obtaining reliable information about sex in Samoa and Samoan ideas of appropriate audiences and places. Defends Mead's appreciation of Samoan conventions on the basis of the consistency of her appendix data on menarche and heterosexual experience. Suggests Freeman's use of the same data to refute Mead invalidates his claims about her unreliability. Quotes Holmes' assessment that Mead's research was remarkably reliable. Downplays the validity of Freeman's statistics and accuses him of failing to account for the variety of culturally determined ways in which adolescent aggression and sexuality are displayed. Discusses, in particular, Samoan patterns of rape, and argues that Freeman's explanations are as cultural as Mead's and that any futher understanding of the variables involved depends on a closer understanding of cultural conceptions of sexuality. Claims Freeman ignores the dramatic cultural changes in Samoa since 1925, citing emigration and remittances, commercialisation, American largesse and economic problems, which have contributed to increased delinquency, youth suicide and possibly sexual permissiveness. Raises questions about Freeman's delay in publishing, calling attention to a 50 page manuscript circulating privately in 1968, and speculating about Mead's knowledge of it. Considers it unfortunate that Freeman has subordinated his ethnography to his critique of Mead and fears the effect of negative stereotypes on Samoans.

Notes and 31 references. 
26. Shore, Bradd. 1983. Paradox regained: Freeman's Margaret Mead and Samoa. Canberra Anthropology 6(1): 17-37. Special Volume: Fact and Context in Ethnography: The Samoa Controversy.

Generally defends Mead's ethnography while acknowledging various deficiencies which anthropologists and Samoanists have long been aware of. Argues that Mead's cultural configurationalism led her to oversimplify and stress unidimensional themes. Supports Freeman's book as a useful corrective to a false popular mythology of the South Seas but accuses him of methodological sloppiness and of sacrificing subtlety and complexity to his efforts to discredit Mead. Disputes ethnological validity of Popperian refutation as human life is riddled with contradictions and incompatible values.

Compares the two accounts as ethnographies dismissing differences in time and place as unimportant. Criticises Freeman's experiments with mothers and babies as unsophisticated and supports Mead's thesis of a greater Samoan diffuseness of attachments. Postulates a "distinct Samoan ecology of emotion" and a "characteristically Polynesian social self" which Freeman has failed to understand and attacks his insistence on residential stability in childhood and the significance of the biological family.

Discusses the issue of sexual promiscuity noting Mead's simplistic and misleading generalizations but defending some of the more penetrating observations in her appendices. Notes that Mead's and Freeman's statistics on virginity are not dramatically different. Enlarges on the conflict between brother/sister and boyfriend/girlfriend relationships, noting that bilateral descent makes any girl a potential sister and suggesting that an act of violence may be needed psychologically to transform the relationship to an erotic one.

Discusses Mead's and Freeman's accounts of hierarchy, obedience and the respect accorded to chiefs, and postulates a double socialisation, in which attitudes of respect and rebellion are both appropriate, as the key to reconciling their views. Notes Mead's negative comments about traditional society in her appendix which contradict the conventional view which associates the darker side of Samoa with Westernisation.

Argues that the theory of the importance of culture in shaping human life cannot, in any case, be refuted by disproving one example and suggests that differences between Samoa and America or England can only be explained by cultural factors. 
Notes and 33 references.

27. Strathern, Marilyn. 1983. The punishment of Margaret Mead. Camberra Anthropologist 6(1): 70-79. Special Volume: Fact and Context in Ethnography: The Samoa Controversy

Discusses Freeman's intentions in attempting to falsify Mead's thesis. Examines some of his contentions and finds it difficult to know what weighting to give the negative instances he produces. Critiques Freeman's examples of how an interactionist paradigm might apply. Discusses the Culture and Personality school in anthropology and compares Mead's and Freeman's understandings of the relation between impulse and culture and finds them very similar. Discusses their representations of Samoan sexuality and rape and attempts to rconcile the two accounts within a wider Polynesian context. Argues that Freeman's male and chiefly viewpoint colours his appreciation of the realities of Samoan society. Contends that Freeman exaggerates anthropology's commitment to cultural determinism.

No references. 
28 Freeman, Derek. 1983. Inductivism and the test of truth: A rejoinder to Lowell D. Holmes and others. Canberra Anthropology 6(2): 96-192. . Special Volume: Fact and Context in Ethnography: The Samoa Controversy

Defends his position on various issues raised in the preceding issue of Canberra Anthropology and replies to individual critics, accusing them of succumbing to inductivism. Proposes Popperian falsificationism as the remedy. Reiterates his understanding of Mead's main theoretical conclusion and its ready acceptance by Boas, Benedict and mainstream anthropology. Accuses Mead of suppressing contrary evidence - discussing the 1926 hurricane, political strife with the American administration and the stoning of a pastor's house while she was on Ta'u. Denies his refutation is an alternative ethnography or a general critique of Mead's ethnography. Details his contacts with Mead and Holmes. Asserts the temporal and geographical homogeneity of Samoan society and the prevalence of residential stability in adolescence. Marshals evidence against Mead's depiction of Samoa as a society practising free love. Defends his data on virginity and recounts anecdotal evidence of the premium placed on virginity by Samoans. Asserts the criminality of moetotolo, citing two Court cases from the 1920 s and providing an interactionist analysis of the practice. Considers the widespread Samoan belief that Mead was duped but denies advancing it as his own contention. Discusses Holmes' 1954 research and notes passages contradicting Mead's account. Quotes a letter from Holmes stating, "Mead finds pretty much what she wants to find.... I was forced by my faculty advisor to soften my criticism..." (p.134).

Discusses Boas' understanding of genetic heredity and biological evolution, noting critical discoveries of the mechanisms involved in the 1930s. Explores Boas' defence of Lamarckian inheritance, his belief in cultural determinism and his antipathy to cultural evolution and genetics.

Attacks Holmes objectivity and his selective use of quotations. Defends his own use of Court records and notes the frequency of reported rape in rural areas has been the same as in Apia.

Criticises Bradd Shore's Sala'ilua as an inductivist attempt to substantiate a theoretical assumption of culture as a symbolic system. Notes the author's failure to interview the murderer and considers that the structuralist explanations advanced obscure such factors as the extreme levels of drunkenness involved. Accuses Shore of getting aga and amio mixed up. Savagely criticises Shore's attempts to reconcile alternative accounts of Samoa and dismisses his theory of double socialisation. Defends his own experiments with maternal deprivation. Claims underlying similarities in diverse cultures require an explanation in terms of a universal evolved primate nature. 
Attacks Schoeffel and Meleisea's characterisation of the 1920 s as a period of stagnation. Argues his youth (younger than Mead when he arrived in Samoa in 1940) and his manaia title facilitated a wide range of friendships with young women. Accuses Schoeffel and Meleisea of making ideologically inspired conjectures and practising a "sociology of ignorance". Rejects the label of a Hobbesian pessimist.

Takes issue with Strathern over infant bonding and punishment and asserts the necessity of falsificationism in the social sciences. Records Jarvie's support and discusses the context in which Mead's Coming of age and Malinowski's Sex and repression in savage society became mainstays of the doctrines of cultural relativism and cultural determinism. Notes the recent publication of refutations of both works.

List of contents, pp.98-99, notes, pp.169-182, and references pp.184-192.

29 Ala'ilima, Fay. 1984. Review of Margaret Mead and Samoa: The making and unmaking of an anthropological myth, by Derek Freeman. Pacific Studies 7(2): 91-92.

Avers that no-one could doubt the existence of both Samoas (those depicted by Mead and Freeman). Expresses unhappiness at Freeman's one-sided focus on the darker side of Samoa. Notes that Mead's stories lured many young Americans (herself included) to Samoa.

No references. 
30. McDowell, Nancy. 1984. Review of Margaret Mead and Samoa: The making and unmaking of an anthropological myth, by Derek Freeman. Pacific Studies 7(2): 99-140.

Attacks Freeman's depiction as Boas as a cultural determinist, his attempts to refute Mead's conclusions about juvenile delinquency and premarital sex in Samoa, and his inaccurate and selective use of quotations. Claims anthropologists generally agree that human behaviour depends on both biology and culture. Notes Freeman's citation of cultural factors in child socialisation to explain various aspects of Samoan culture and his failure to give more than one example of an interactionist explanation. Dismisses this example (of Samoan respect language as a development to inhibit potentialities for conflict in fono) as demeaning the complexities of behaviour and failing to account for cultural diversity. Argues that biological (physical) anthropology has always been regarded as important in America. Cites research by Boas on head shapes of immigrant children and biological factors affecting longevity as evidence that he was not a cultural determinist but had an abiding interest in biological factors.

Questions the relevance of Freeman's 1940s research in Western Samoa to Mead's findings. Notes the contradictory nature of Mead's evidence about premarital sex and ascribes it to the gap between the ideal and the actual. Attacks Freeman's figures on virginity and his use of British and Samoan statistics on rates of juvenile delinquency. Notes Mead's attribution of maladjustment to fundamental discrepancies between individual temperaments and their cultures as evidence that she did not discount biological variables. Quotes Shore in conclusion - that Mead and Freeman are both right and wrong, because culture is complex and full of contradictions, and different male and female perspectives will inevitably produce differing accounts.

Notes and 32 references. 
31. Wendt, Tuaopepe Felix S. 1984. Review of Margaret Mead d and Samoa: the making and unmaking of an anthropological myth, by Derek Freeman. Pacific Studies 7(2): I: 92-99.

Describes his own reactions to Coming of age, which he had reaad three or four times by the time he was 17 , finding great difficulty in recognising in it any aspects of his own upbrininging in a strict religious household. His conclusion was that many things in it were incorrect and that it had been based o on superficial and shoddy research.

Observes that Freeman's work is an able refutation but expresseses reservations about the atmosphere of evangelical puritanism, authoritarianism and punishment he depicts, as being ig recognisable but one-sided. Asserts that alofa is the overiding ethos of Samoa and Freeman should have given a morere balanced account. Attacks Freeman as a pseudo-Samoan and another disenchanted palagi academic in exilxile from his own society, portrays his book as a betrayal of his adoptive country and fears its effects will be negative. Rececords his personal view (shared by most Samoans) that Margaret Mead was duped.

No references. 
32. Freeman, Derek. 1984. Response [to Ala'ilima, Wendt and McDcowell]. Pacific Studies 7(2): 140-196.

Replies briefly to Ala'ilima and Wendt, stressing the importance of f the truth and reiterating his love and admiration for the people of Samoa. Depicts McDowell as a cultural determinist aand and admirer and associate of Mead. Argues dominance is a part of human ethology in defence of his interactionitist explanation of respect language. Contends that physical or biological anthropology may have been a part of Americcan anthropology but it has always been carefully segregated from cultural anthropology. Produces evidence from pubblications of Boas and his students to support his claims that Boas believed in Lamarckian inheritance, was antipathetitic to biological evolution and skeptical about Mendelian heredity, particularly as it applied to humankind.

Defends the cultural unity of Samoa and dismisses the time gap as a I factor, claiming that in any case the primary evidence for his refutation comes from Mead's own data and from ccontemporary historical records. Comments on his alleged lack of understanding of the ideal/actual question and refutesss several of Mead's generalizations about the ideal. Outlines the methodology he employed in collecting data on virginityy in Sa'anapu. Maintains his $20-40 \%$ figure for sexual experience represents illicit behaviour which encounters sociaal disapproval and punishment. Defends his use of comparative statistics from other countries as approximate but illumininating. Quotes Holmes'personal comments to him and claims Holmes really disagrees with many of Mead's conclusionsss.

Devotes considerable space to Mead's claim that the idea of forceful 11 rape is completely foreign to the Samoan mind. Affirms that rape has always been relatively common in Samoa (incluluding American Samoa in the 1920s), is severely punished, and is a major cause of stress for unmarried Samoan wommen. Notes what he calls McDowell's bizarre attempt to claim Samoan rapists may only be trying to obtain wives. Claims is moetotolo involves force not just deceit. Describes occasions when he has personally been part of groups of young men a exchanging information on techniques for rape and moetotolo. Records that adultery was a crime in Samoa in 1926 and d claims that punishments were severe and often

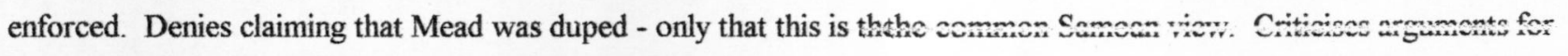
different male and female vantage points claiming close friendships w with many Samoan women.

Attacks McDowell's claim that Bradd Shore shows a better understastanding of Samoan culture in his book Sala'ilua. Depicts Shore as a cultural determinist "purporting to explain an impnpetuous and violent murder by one drunken chief of another in terms of 'cultural structure"'. Considers his understandingng of amio and aga (nature and culture) is completely 
back to front. Cites the 1926 journal of A.F. Judd about an affray in Ta'u which Mead knew about but ignored because it didn't conform with her thesis. Cites the suspension of an American Samoan chief by the American naval government as evidence that people did suffer for their convictions. Denies claiming he has proved adolescence is equally stressful in all cultures, only that Samoa can no longer be cited in support of the cultural determinist cllaim that biological variables are of no significance in the etiology of adolescent behaviour.Defends charges of devious misquotation at length, accusing McDowell of pedantry and desperation.

Notes and 85 references.

33. Appell, G.N. 1984. Freeman's refutation of Mead's coming of age in Samoa: The impliczations for anthropological inquiry. The Eastern Anthropologist 37(3): 183-214.

Unreservedly supports Freeman's refutation and his arguments for an interactionist paradiggm for anthropology. Affirms Freeman's conclusions in the areas of competition, aggression, religion, punishment, childrrearing, Samoan character and sexual mores and his explanations of the sources of Mead's errors. Discusses "organic/connfigurationalist" versus "repressive" interpretations of cultures and the contention that anthropologists' depictions s of societies reflect their pre-existing biases and assumptions but rejects it in the present instance on the grounds thanat the Mead/Freeman argument is about facts not interpretations. Criticises Mead for allowing personal and ideozological biases to interfere with her scientific objectivity. Mentions internal contradictions between her data and interprpretations and notes various pre-World War II criticisms of her ethnographic reliability. Adduces various reasons for th the unprecedented hostility of American anthropologists to the publication of Freeman's critique, including Mead's statusus as a culture heroine and mythic figure, the ideological nature of cultural determinism and its role in underpinning cucultural relativism and the confusion of Freeman's stance with sociobiology. Attacks American anthropology for infeeferior standards, lack of development and according divinity status to culture. Concludes by outlining his understartanding of interactionism and the possibilities it opens up for evaluating different sociocultural systems, postulating correrrelations between biological factors such as life expectancy and adaptional effectiveness.

Notes and 49 references. 
34. Caton, Hiram. 1984. Margaret Mead and Samoa: In support of the Freeman critique. Quadrant (March): 28-32.

Criticises responses from the anthropological profession and disparages what he calls Mead's transparent island paradise myth. Postulates the German historical school with its emphasis on the uniqueness of national experience in the formation of national culture and mentality as the progenitor of cultural determinism and acccuses anthropology of degenerating into a search for the exotic, uninformed by any general theory to describe and explain what is common among cultures. Suggests cultural determinism requires a cultural paradise if it is to be at the same time a doctrine of hope - that reform is possible by removing repression in childrearing. Locates Coming of cage within the broad stream of Wilsonian reform politics. Claims anthropologists must now accept Freeman's interactioniist paradigm or defend Mead's fantasy with vilification and obscurantism. Contends anthropology cannot uphold the myth 1 of man's infinite diversity without attacking every other science of man. Notes Freeman's appointment as Professor r of Anthropology and Pro-Vice-Chancellor at the University of Samoa.

No references.

35. Levy, Robert I. 1984. Mead, Freeman and Samoa: The problem of seeing things as they a are. Ethos 12(1): 85-92.

Discusses the impact of Freeman's book at a time of soul-searching for anthropology and e: expresses some disappointment at his analysis of cultural determinism. Suggests Popper, as a non-Positivistst, held a more restricted notion of the domain of science than Freeman. Indicates a preference for a reconciliation of of the two accounts of Samoa as representing the differing viewpoints of adolescents and the guardians of religious and pcpolitical order. Canvasses Samoan and Melanesian responses to Mead's and Freeman's anthropology. Constructs an a argument in support of different levels of awareness of one's own culture, foreshadowed by Gregory Bateson in hishis theory of third level learning but rejects any implication of radical relativism. Typifies many of the communities es studied by anthropologists as total institutions in the sense defined by Erving Goffman (1961) and contrasts these with momore sophisticated and literate cultures in cultural self-awaremess. Argues for anthropology as a science.

Notes and 13 references. 
36. Nardi, Bonnie A. 1984. The height of her powers: Margaret Mead's Samoa. Feminist Studies 10(2): 323-337.

Denounces Freeman for his attempt to sully Margaret Mead's reputation when she is no longer able to defend herself. Views Freeman's book as an underhand attack on feminism and a "celebration of society's abhorrence of sexual and intellectual freedom for women".

Refers to a general awareness among anthropologists of Mead's errors and limitations and considers Freeman is basically correct on Samoan competition for rank and status, on significant levels of violemce and jealousy and the parental and societal prohibitions on premarital sex. Accuses both anthropologists of overr-generalisation. Dismisses cultural change in the interim as an explanation and focuses instead on the different sectionns of the Samoan population under study. Maintains that Samoan girls are not granted sexual freedom but assert it on ttheir own, that there are considerable opportunities for sex, and many illegitimate children. Claims Samoan womem are not prudish about sex. Dismisses Freeman's claims about Samoan male attitudes to rape as an ethnic slur and acccuses Freeman of displaying excessive interest in the details of the cases he describes. Denounces his statistics on rape $ə$ as misleading in that they are not age-adjusted and don't take into account the high levels of non-reporting in both Samnoa and the United States.

Considers Freeman's speculation about whether Mead was hoaxed as "the lowest blow", , and attacks him for ageist and sexist bias in not believing the information that girls gave Mead about their own lives.

Contends Freeman's attempt to link his refutation of Mead's ethnography with a general al attack on cultural determinism is dishonest, and accuses him of making common cause with sociobiologists. Notes the lalack of any real evidence in support of his interactionist theory.

The author spent a year in a Samoan village in 1980, studying reproductive decision-makiking. Bibliographical notes. 
37. Scheper-Hughes, Nancy. 1984. The Margaret Mead controversy : Culture, biology and anthropological inquiry. Human Organization 43(1): 85-93.

Examines Freeman's claims to have refuted Mead's ethnography and finds they fail on theeoretical grounds, no such refutation being possible in anthropological enquiry. Compares the controversy with reactitions to her own published research on rural Ireland, which stressed economic, psychological and social problems andd contradicted earlier authoritative ethnography. Notes similarities in Freeman's and Mead's approaches - for exxample, the culturalist nature of Freeman's claim that corporal punishment produces hostility and aggression in Samoann men. Decries his failure to deliver on promises of a new interactionist paradigm, referring to it as a tired and outmodeded stratigraphic model where culture is seen as a veneer covering deeper passions and emotions. Considers that the exprpression of emotion is as much cultural as the mechanisms of social control. Suggests moetotolo is better translated as manarriage by capture in many cases and should not be included statistically with rape. Attacks Freeman's description of ff primary mother-child and nuclear family bonds in Samoa as manifestations of a universal biological instinct, referringng to various cultures and situations where such feelings do not exist. Contends that ethnographical accounts cannotot be separated from the anthropologist who wrote them and that Mead, as a young women and Freeman, as a mididdle-aged man would inevitably have different and unreconcileable perspectives.

Regrets loss of authority for social scientists generally as one result of the controversy anand praises Mead's role in getting "culture" accepted as the basic reason for human differences, in widening opportunities fo for women, in the civil rights and anti-war movements and, together with Dr Spock, in creating a climate encouraging g communication and permissiveness in childrearing among her parents' generation.

39 references. 
38. Ember, Melvin. 1985. Evidence and science in ethnography: Reflections on the Freeman-Melead controversy. American Anthropologist 87(4): 906-910.

Attacks Freeman's claims to have refuted Mead's observations on the basis that their studies b were carried out in different places at different periods. Decries the lack of objective evidence in both ethnographihies, claiming that only systematic random sampling of behaviours by a number of different information gatherers can $\mathrm{n}$ produce statistically significant data. Describes variations he found in three Samoan villages in his own fieldwork in in 1955-56 (researching correlations between remoteness, commercialisation and political autonomy). Suggests increaeasing commercialisation and urbanisation as reasons for Mead's and Freeman's divergent conclusions. Accuses Freeman o of being authoritarian and aggressive in accusing both himself and Mead of being ignorant of certain facts about Polynesesia. Contends people are receptive to genetic explanations of cultural differences when they want to justify social ineququalities. Fears anthropology has been made to look foolish and suggests Freeman's book should not have been published. I.

Notes and 6 references.

39. Freeman, Derek. 1985. A reply to Ember's reflections on the Freeman-Mead controversy. A American Anthropologist 87(4): 910-917.

Claims Ember is defending his 1973 anthropology textbook which endorsed Mead's conclusiosions. Defends the scientific nature of his attack on Mead by quoting Popper on verificationism versus the critical method id of error elimination. Notes the relative ease of falsification as opposed to verification in relation to several of Mead's monore extreme generalisations about rape, jealousy and war in Samoa - quoting from official statistics and Court records of af American Samoa.

Maintains one primary source of refutation is found in Mead's own data. Argues that Ta'u anand Sa'anapu were similar enough to justify comparison and that Mead's historical generalisations can be refuted by refe:ference to historical texts. Cites 1967 statistics of rape and "criminal aggression" in Western Samoa to refute suggestionons that this type of crime is predominantly an urban phenomenon. Examines Mead's pre-existing knowledge of Western h Polynesian cultures in 1926. Details pre-publication support for his book from Samoan academics and publishing offers frefrom other academic presses. Notes and 36 references. 
40. Hooper, Antony. 1985. Review of Margaret Mead and Samoa: The making and unmakimg of an anthropological myth, by Derek Freeman. Oceania 55(3): 224-225.

Suggests the special review sections in American Anthropologist, Pacific Studies and Canboerra Anthropologist as the best means of informing oneself about the points at issue in the controversy. States Freemann has made no headway with his interactionist paradigm and contends his positivist approach to social facts means he igncores the most interesting current debates in social theory. Praises Freeman for drawing attention to Mead's shortcominings and avers that his own views about Samoa are closer to Freeman than Mead. Deplores Freeman's adversary tactics s and hopes he will produce a more rounded ethnography in the future.

References not noted.

41. Reyman, Jonathan E. and Joyce D. Hammond. 1985. Some comments on the Freeman-Me/ead controversy. American Anthropologist 87(2): 393-394.

Attacks Freeman's failure to distinguish between 'ideal' and 'real' culture. Claims a cult of vf virginity prevailed at the ideal level in the United States in the 1950s and early 1960s, while in reality premarital sexuaual intercourse was a fact of life for most. Similarly, studies indicate that in the majority of marriages at least one partner er engages in extramarital sexual activity.

No references. 
42. Freeman, Derek. 1985. Response to Reyman and Hammond. American Anthropolodogist 87(2): 394-395.

Refers Reyman and Hammond to page 239 of his book, claiming he is fully aware of tif the distinction. Quotes Holmes, Shore, Schoeffel and Meleisea, and Wendt in support of his contention that Samoa hahas always prohibited premarital and extramarital sex as an ideal. Notes that Mead's survey showed over $50 \%$ of the girls is in her sample were virgins.

Outlines the methods and assumptions he used in his own survey which found a figurere of $73 \%$. Quotes assertions by Mead (1959) and Honigman, J.J. (1963) about Samoan sexuality which he considers as are totally at variance with the ethnographic facts.

Notes and 9 references. 
43. Young, R.E. and S. Juan. 1985. Freeman's Margaret Mead myth: The ideological virgiginity of anthropologists. Australian and New Zealand Journal of Sociology 21(1): 64-81.

Generally supports Freeman's refutation of Mead's account of Samoa but claims it fails s conspicuously as an argument about the nature of anthropology. Suggests anthropologists were already well aware of pf problems with Mead's work and that the proper audience for the book is rather the educated public. Outlines Freemanan's contentions about the development of anthropology and the genesis of Mead's Samoan fieldwork and succinctlctly summarizes his ethnographic evidence in contradiction of her findings. Attacks Freeman's depiction of mainstream an anthropology as supporting cultural determinism, citing the widespread interest in physical anthropology in Americarcan universities. Quotes from anthropological textbooks on the effects of culture on genotype and from Kroeber and Bt Boas on the importance of hereditary factors. Quotes Mead in rejection of cultural relativism. Records various critiriticisms of Mead from the 1930s on. Argues Boas' influence on Mead has been exaggerated.

Cites other examples of studies proving aggression is caused by cultural factors and noteotes that disproving a single instance does not disprove a theory. Criticises Freeman's use of statistics and overstatentement and suggests the book will appeal to proponents of various right-wing doctrines. Suggests (absolute) cultural detenterminism is a "straw man" and the proper debate is about the degree to which biological and cultural explanations should bd be stressed with one position being that of cultural maximalism.

37 references. 
44. Patience, Allan and Joseph Wayne Smith. 1986. Derek Freeman and Samoa: : the making and unmaking of a biobehavioral myth. American Anthropologist 88(1): 157-162.

Attempts to show that Freeman's refutation is based on a misapplication of an $\mathrm{n}$ in any case fundamentally unsound Popperian metascience and criticises his biobehavioral model of culture. Suggejests a comprehensive cross-cultural comparison of family life would be necessary to falsify Mead's thesis that comining of age in Samoa was easier than in the United States. Argues for reconciling both representations of Samoan sexualityty, suggesting different rules for taupou and commoners and noting differences in time and place. Emphasises that refututing Mead does not logically invalidate Boasian cultural determinism. Discusses Popperian assertions about scientific t: truth and rejects Popperian epistemology as rationally unacceptable. Criticises Freeman's interactionist paradigm as unrereconcileable with Popperian requirements and considers his notion of a biobehavioral basis to behaviour quite resistant tc to falsification.

14 references. 
45. Freeman, Derek. 1986. Rejoinder to Patience and Smith. American Anthrotopologist 88(1): 162-167.

Asserts that Mead's principal conclusion was that biological variables are of nf no significance in the etiology of adolescent behaviour, not that coming of age was easier in Samoa. Denies the possibilityity of reconciling his and Mead's views on sexuality. Denies concluding that Mead's informants must have lied but notes es this view is widely held in Samoa. Affirms the cultural uniformity of Samoa. Denies claiming his refutation of Mead dispssproves Boasian cultural determinism, contending only that Mead's researches can no longer be cited in support of itf it. Accuses Mead of making claims which could have been readily contradicted by reference to contemporary newspapeipers and court records and historical accounts. Defends Popperian theories of criticism and scientific progress as de deriving from a long tradition. Denies advocating a biobehavioral paradigm, but affirms the importance of both bioldological and cultural variables in human behaviour. Describes the ideological position of absolute cultural determinismism embraced by Boas, Lowie and Mead and laid out in Kroeber's eighteen professions of $1915^{4}$.

Notes and 57 references. 
46. Rappaport, Roy A. 1986. Desecrating the holy woman: Derek Freeman's attattack on Margaret Mead. The American Scholar. 55(3): 313-347.

Expresses anthropologists' annoyance at disproportionate media interest in a cc controversy about two books of little real importance to theoretical debates within the discipline. Affirms that Coming of of age in Samoa contained errors had long been known among anthropologists. Explores Mead's real significance in the te twentieth century as a generator of myth in the most positive sense. Examines the nature of myth as an idealised picture re of the world as it should be and suggests that myth has its own type of truth, invulnerable to falsification but susceptible tle to withdrawal of acceptance. Links Mead's mythmaking to the sexual emancipation of women and the struggle agaigainst racism and compares it to the ugly eugenicist myths of the inter-war geneticists. Denies Boas and Kroeber were ab absolute cultural determinists and attacks Freeman's motives, methods and conclusions, describing his chapters on Boas is in particular as muddled, perverse and mischievous misrepresentations. Argues that the vague generalisations of anthrthropology are not susceptible to formal Popperian falsification. Aligns Freeman with the eugenics movement, the Ku Kı Klux Klan and Adolf Hitler, viewing his "interactionist" paradigm as calling for the re-attribution of cultural differences es to biological variance among races. Concludes with an outline of the contemporary anthropological consensus abouout evolution, culture and heredity, with culture being a constructed and accepted order of phenomena based upon symbmbols which creates meaning and a basis for organising human action, and evolution revealing a human brain essentially ty unchanged biologically despite the vast elaboration of culture in the last 40,000 years

References not noted. 
47. Holmes, Lowell D. 1987. Quest for the real Samoa: The Mead/Freeman controversy \& beyonal. South Hadley, Mass.: Bergin \& Garvey.

Holmes spent 9 months in Manu'a and Ta'u in 1954 doing fieldwork for a restudy of Margaret Meead's conclusions from 1926. The book is a sustained rebuttal of Freeman's depictions of Boasian determinism and Samoaan society and a qualified defence of Mead's original conclusions.

Details methods used to gather information and limitations imposed by language and informant retiticence on sensitive issues. Describes the Samoan society he saw in 1954 with particular attention to rank and village ccouncils, Christianity and childcare. Rejects the counter-hypothesis of significant cultural change in the period 1926-19554. Assesses Mead's findings in the light of his own research, concluding that "the validity of her Samoan research is remmarkably high". Expresses reservations, however, about the degree of sexual freedom and the lack of competition pportrayed by Mead. Postulates that Mead's youth and sex gave her a different viewpoint in these areas.

Briefly summarizes a number of psychometric studies of Samoan character. Assesses Freeman's crititique of Mead and finds it deficient in numerous areas. Contends that much of Freeman's evidence is taken from other, $\mathrm{r}$, more urbanised parts of Samoa and from a different era and is therefore irrelevant to any discussion of Ta'u in 1926.6. Attacks Freeman's motives, methods, scholarship, integrity and conclusions and accuses him of ethnocentric bias as a New Zealander. Comments on various Samoan responses to Freeman's depiction of Samoa.

A postscript by Eleanor Leacock entitled The problems of youth in contemporary Samoa ascribes m more recent levels of juvenile crime and suicide (factors used by Freeman to support his claims of universal difficulties in a adolescence) to colonisation, unemployment and the breakdown of traditional social control mechanisms. x, 209pp. Index and bibliography, pp.195-201. 
48. Freeman, Derek. 1987. Comment on Holmes's "Quest for the real Samoa". American Anthropologist 89(4): 930-935.

Claims Holmes basically ignores his refutation of Mead's major conclusions in the area of adolescent disturbances and social environment. Focuses on rape, sexuality and intervillage strife and cites examples of Holmes contradicting his own conclusions and selectively altering the wording of critical sections of the book lifted from his dissertation to bolster his defence of Mead. Criticises Holmes' lack of Samoan language and the briefness of his stay in the islands. Notes that he (Freeman) was younger than Mead when he first arrived in Samoa in 1940 and speaks of his leadership of the Sa'anapu 'aumaga and his close friendships with several Samoan girls. Quotes Albert Wendt and Aiono Dr Fanaafi Le Tagaloa as Samoan expert evidence in his favour. Dismisses as fatuous Holmes' claims that his relations with Samoans were jeopeardised by his New Zealand nationality. Accuses Holmes of failing to understand the nature and purpose of scholarly refutation. Dismisses Eleanor Leacock's postscript as the product of only 10 weeks in Samoa. Notes and 31 references.

49. Freeman, Derek. 1987. Review of Quest for the real Samoa: The Mead/Freeman controversy and beyond, by Lowell D. Holmes. Journal of the Polynesian Society 96(3): 392-395.

Claims Holmes' book is an example of the "Festinger reaction" or the response of a believer "when prophecy fails". Accuses Holmes of selective quotation and ignoring Mead's own data on deviant and maladjusted individuals. Notes evidence from Holmes Ph.D. dissertation which contradict some of Mead's generalizations about Samoan sexuality and aggression. Claims Holmes has misunderstood the nature of a refutation.

8 references. 
50. Laing, Patricia Kinloch. 1987. Review of Quest for the real Samoa: The Mead/Freeman controversy and beyond, by Lowell D. Holmes. Journal of the Polynesian Society 96(3): 395-400.

Compares the Mead/Freeman controversy to a Samoan fa' atau in which talking chiefs try to outdo eachother for the honour of being chosen as the best orator. Denies the concept of a single "real Samoa" or a single real version which can be discovered scientifically and questions the utility of quibbles over ethnographic detail. Notes ethnographic bias and the role of the observer as important factors in anthropological understanding and criticises Popperian notions of science which don't take these factors into account. Contrasts "scientific" attempts at standardisation, reliability and validity with an acceptance of multicultural diversity, imspiration and creativity.

24 references.

51. Bargatzky, Thomas. 1988. Review of Quest for the real Samoa: The Mead/Freeman controversy and beyond, by Lowell D. Holmes. Pacific studies 11(3):131-151.

Finds the book disappointing and depressing, "a desperate attempt to buttress earlier conclusions". Attacks Holmes for republishing earlier material and ignoring Freeman's subsequent replies to various charges, and notes inaccuracies in his ethnography and prehistory. Accuses Holmes of self-contradiction, omission and evasion and repeats the story that he refrained from criticising Mead for fear of losing grants.. Quotes from Holmes' own ethnography to refute his agreement with Mead on sexual freedom in Samoa. Criticises him for misrepresenting Freeman's interactionism as sociobiology. Denounces the use of Napoleone Tuiteleleapaga's statements in support of Mead's ethnology in the light of Holmes' earlier reports on his deviousness and unreliability. Defends the genuineness of Freeman's Samoan title. Attacks Holmes' attempts to portray Ta'u as culturally isolated from the rest of Samoa, asserting a comparable degree of isolation for Sa'anapu (site of Freeman's study) in 1941-43. Comments on the unprecedented levels of opprobrium and vilification directed at Freeman and attempts to deny him effective reply to his critics. Criticises cultural relativism as self-contradictory and ethically dangerous.

Notes and 57 references. 
Margaret Mead and Derek Freeman: Bibliography of a controversy

52. Appell, G.N. and T.N. Madan, eds. 1988. Choice and morality in anthropological perspective: Essays in honour of Derek Freeman. Albany, N.Y.: State University of New York Press.

A festschrift from Freeman's students for his 70th birthday. A 22 page introduction, by G.N. Appell, entitled Derek Freeman: Notes towards an intellectual autiobiography, states the case for the "interactionist paradigm", which rejects cultural relativism for a science that will "evaluate cultural behaviour in terms of its cognitive accuracy in mapping reality and its adaptive value, which focuses on the discovery of universal principles of cultural dynamics and sees customs as adaptational innovations for dealing with pre-existing emotional and behavioural proclivities of human beings". The introduction continues with an outline of Freeman's fieldwork in Samoa and Borneo, his academic career at A.N.U., his disillusionment with current anthropological theory, his studies in ethology, evolutionary biology, primatology, neurosciences, psychology and genetics and the development of interactionism as a new approach.

The remainder of the book consists of ethnological essays on various societies in Papua-Niugini and Indonesia. $\mathrm{xv}, 248 \mathrm{pp}$. Index and references. 
53. Feinberg, Richard. 1988. Margaret Mead and Samoa: "Coming of age" in fact and fiction. American Anthropologist 90(3): 656-663.

Argues that a careful reading of Coming of age does not corroborate the view that Mead saw Samoa as a romantic paradise. Suggests a discrepancy between the popular perception and Mead's actual account. Considers Freeman has performed a useful service in making the educated public aware of the inaccuracies in Mead's glib generalisations.

Quotes passages painting an idyllic image and accuses Mead of a tendency to exaggerate and oversimplify. Considers sections and claims conflicting with this image chapter by chapter - in relation to competition among men for rank, the burdens of the taupou, the isolation of certain individuals, sexual relations out of wedlock, personality and stress, and Mead's specific examples of deviance and maladjustment. Suggests that Coming of age is really two books - one an ethnography and the other a message to parents and educators. Attributes Mead's inconsistencies to oversimplification as a result of writing for a popular audience, a general bias in ethnography to reporting the startling and different rather than the expected and mundane, and Mead's sense of mission. Argues, however, that critical readers should have been able to find sufficient information in the ethnographic portions of the book.

Notes and 8 references. 
54. Foerstel, Lenora. 1988. Margaret Mead: From a cultural/historical perspective. Central Issues in Anthropology 8:25-35.

Describes the intellectual background to Boas', Benedict's and Mead's fight against racist ideologies in the early 20th century, and stresses the Freudian origins of the ideas of instinct and frustration. Discusses wartime applications of cultural personality theories of culture in studies of Japanese and German societies by Benedict and others, which saw particular child-rearing practices as producing anti-democratic personality characteristics in these countries. Portrays a Western ethnography studying the third world through a distorting individualist lens. Notes inaccuracies in Mead's description of Tchambuli culture and ascribes them to her limited and seasonal acquaintance with the society. Mentions allegations of racism against Mead from "rising new scholars" of Papua-Niugini for her depiction of the Manus as a society unique in the region in its ability to adapt to the impact of the 20th century, and for her unfavourable comments about other groups. Notes an indigenous view of anthropologists as "co-conspirators in neo-colonialism". The author did fieldwork with Mead in Manus in 1953.

13 references. 
56. Leacock, Eleanor. 1988. Anthropologists in search of a culture: Margaret Mead, Derek Freeman $n$ and all the rest of us. Central Issues in Anthropology 8:3-23.

Lists previous criticisms of Freeman's work, including misrepresentation of Boas, selectivity in citatation, ignoring the effects of capitalist penetration and colonization, ignoring other instances of untroubled and sexuallily permissive adolescence. Accuses him of an ideologically motivated attack on a leading female scholar and of s'substituting a negative stereotype about Samoans for a positive one, insensitively ignoring possible harmful effectcts on Samoan emigrant communities. Criticises Mead for failing to see tensions below the surfaceof Samoan sociciety, and ignoring colonialism. Admits a degree of romanticisation in Mead's depiction but excuses it as a useful counnter to Western ethnocentricity. Sees any role for biological determinism as racist and as providing a basis for renevewed Western hegemonic claims. Criticises Freeman's portrayal of the impact of Christianity and asserts a differerent model, backed with extracts from missionary accounts, which emphasises successful Samoan resistance to Victoriarian mores and ethics. Contrasts a traditional anthropology, often unwittingly committed to maintaining the status quo, wiwith an applied, advocacy anthropology, which works with the oppressed for social change - incidentally gaining thethereby much greater acceptance in the community under study. Raises the problem of traditional inequalities but notes th that, in Samoa, women can appeal to tradition in asserting status and rights, as male domination is a Western norm. Calls fs for a historically oriented, advocacy-linked anthropology to be carried out in collaboration with the local people, thahat sees culture as multi-faceted and flexible, and a resource to be drawn on in relation to contemporary needs Notes and 31 references. 
57. Mageo, Jeannette Marie. 1988. Malosi: A psychological exploration of Mead's and Freeman's work and of Samoan aggression. Pacific Studies 11(2): 25-65.

Critiques Mead's and Freeman's views of Samoan culture in the light of her own knowledge of Samoa. The author is married to a Samoan and has lived in Samoa for 6 years. Begins with a semantic analysis of relevant Samoan words and attitudes to violence and force. Succinctly outlines Mead's conclusions about Samoa, stressing Mead's theoretical roots in Freudian psychology. Generally agrees with Freeman's contentions but attacks him on a number of points - that he mistakenly aligns Mead with behaviorism in psychology, his ethological position on human aggression. Supports Freeman in locating the origins of aggression in heavy-handed punishment of children. Repudiates Leacock's general contentions about the deleterious effects of Christianity and Western civilization, but cites a number of sociological explanations for increasing problems in recent years. Discusses the expected submission/dominance, humility/authority relationship between child and parent, elder and younger sibling, wife and husband. Explores the theme of dominance/submission in adult life in the quest for rank and titles. Considers aspects of punishment, rejecting Freeman's depiction of it as capricious because in Samoan terms the insubordinate attitude is more important than the magnitude of the offence. Notes that punishment confirms the status of the punisher. Comments on peer group rivalry and inter-group conflict. Illustrates her contentions with examples from her own experience.

Notes and 56 references. 
58. Paxman, David B. 1988. Freeman, Mead, and the eighteenth century controversy over Polynesian society. Pacific studies 11(3): 1-19.

Argues that the disagreement between Mead and Freeman over the nature of Samoan society is only the latest development in a debate which first began in the eighteenth century, and is ultimately unresolvable, given the problems of subjectivity, interpretation and the reliability of informants. Suggests that speculation about the nature of humankind in the light of cultural differences will always reflect the predispositions of the observer. Presents extracts from eighteenth century sources locating the causes of cultural difference in environmental and climatological factors.
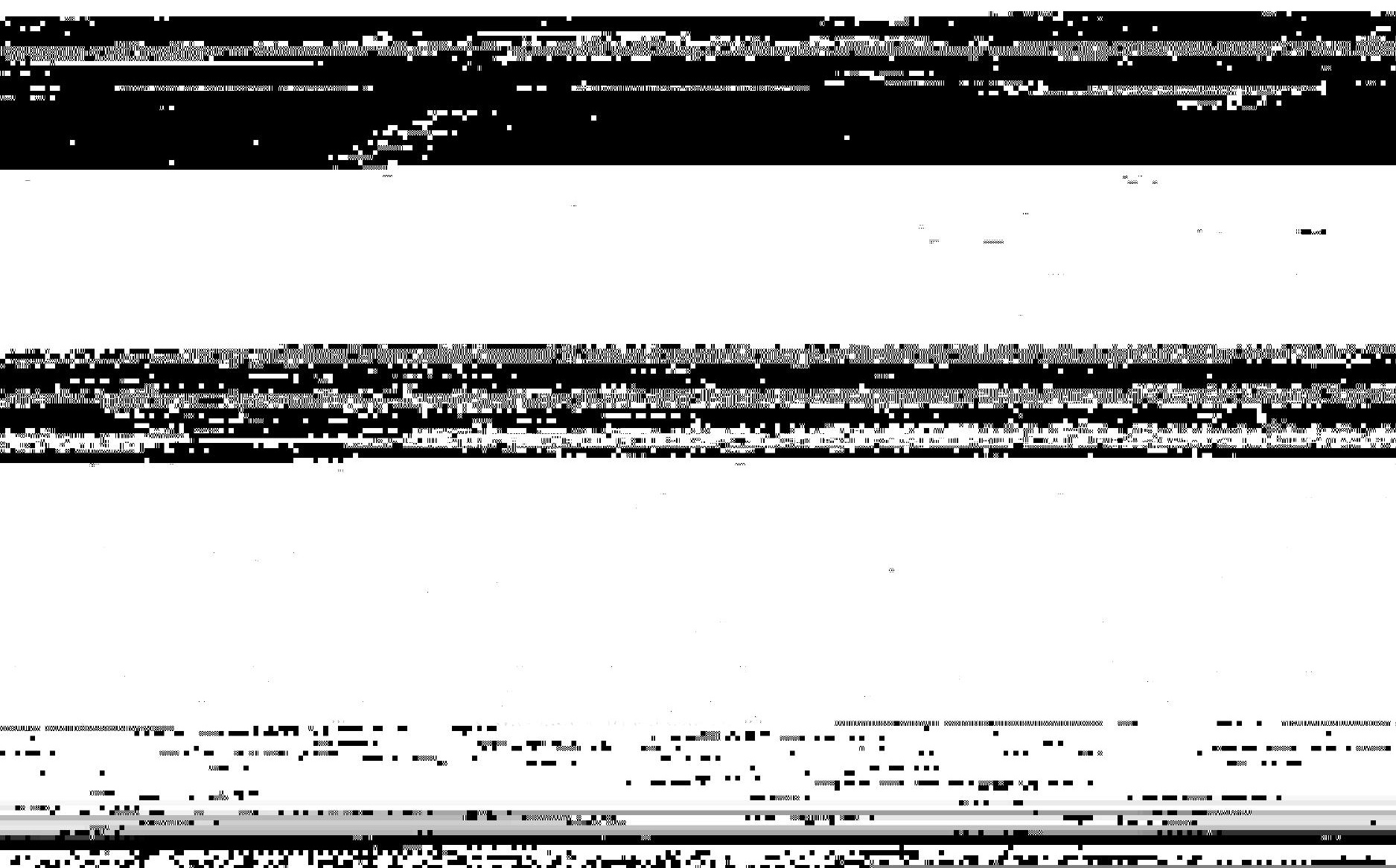
60. Freeman, Derek. 1989. Fa'apua'a Fa'amu and Margaret Mead. American Anthropologist 91(4): 1017-1022.

Cites three written sources which mention the Samoan story that Mead was the victim of fibbing pranks "tau fa'ase'e" or "tau fa' alili" as explanation for her accounts of Samoan sexual mores. Outlines Fa'apua'a Fa'amu's background and her 1926 friendship with Mead as an English-speaking companion on various trips to other villages. Gives a transcript (in English and Samoan) of a sworn statement she made to the Secretary of Samoan Affairs in the Government of American Samoa in 1987, claiming she was "just joking" (ula i ai) and "fibbed and fibbed" (o le pepelo, pepelo a i ai matou) about what she "did at nights", that Mead never checked or challenged the stories they told, and that, in reality, sexual morality was very strict.

Affirms the veracity of the testimony on the basis of it being made in public to a high chief and sworn on the Bible by a devout Christian. Claims there is now a convincing explanation for Mead's account being so much at odds with others. Notes and 17 references. 
61. Caton, Hiram, ed. 1990. The Samoa reader: Anthropologists take stock. New York: Lanham.

Presents a large number of excerpts from most of the significant books and journal articles about the Mead/Freeman controversy and background material on theories of cultural and biological determinism. . Sections cover theories of culture, Samoan ethnography and ethnographic method, the history of the controversy and professional ethics in anthropology. Most of the excerpts are from 3 to 6 pages in length and each section begins with a slightly longer introductory essay by the editor. Derek Freeman contributes several special essays in response to various criticisms, comments on his relationships with Margaret Mead and Lowell D. Holmes and publishes correspondence with the latter and with Alexander Kohn.

Most of the extracts are taken from scholarly articles in anthropological journals but other, more personal material conveys something of the emotional side of the controversy. The overall impression is generally sympathetic to Freeman but opposing vewpoints are also presented. Contributors include Margaret Mead, Phyllis Grosskurth, Bradd Shore, Robert I. Levy, Alfred Kroeber (his "eighteen professions" of 1914), Clifford Geertz, Roy A. Rappoport, Robin Fox, George N. Appell, Jeanette Mageo, Marvin Harris, Lowell D. Holmes, Thomas Bargatzky, Mary Lefkowitz, Robert Levy, Hiram Caton, Nancy McDowell, Lola Romanucci-Ross, Richard Goodman, Allan Patience, Sir Edmund Leach, Annette B. Weiner, Ivan Brady, Bradd Shore and Richard Basham.

Notable individual items include an outline, by the editor, of Freeman's intellectual development and career in anthropology, a 1929 article by Mead in Parents' magazine about adolescence in Samoa, an anonymous referee's report on Freeman's Margaret Mead and Samoa and a letter from Margaret Mead to Richard Goodman commenting on Samoan vulnerability to small insults and slights in the light of the experience of host nations of Samoan communities abroad and on the sheltered, alcohol-free position of Ta'u in 1926.

xii, 351pp. Index and bibliographies pp. 333-345. 
62. Murray, Stephen O. 1990. Problematic aspects of Freeman's account of Boasian culture.

Current Anthropology 31(4): 401-407.

Accuses Freeman of using selective quotation to misrepresent the views on heredity, culture and evolution held by Boas, Lowie, Kroeber, Sapir and other American anthropologists and to exaggerate their closeness as a group. Emphasises Mead's non-acceptance by mainstream American anthropology and contends Freeman has inflated her real importance. Lists disagreements on fundamental issues between those labeled Boasians by Freeman, and Boas' isolated position in the profession during the war years. Denies a pivotal role for Boas in setting Mead's research agenda and contends Ogburn and Wissler may have been more influential. Claims the doctrine of cultural determinism was generally accepted by 1926 and Boas was not particularly interested in Mead's proposed fieldwork. Notes skepticism about Mead's research and findings on the part of Lowie, Kroeber and other anthropologists of the 1930s and argues Freeman's claims of uncritical acceptance are unfounded. Notes Mead's stronger theoretical links with Benedictian cultural configurationalism and mentions with surprise the uncritical acceptance of Mead's Coming of Age by British Empire Oceanists who should have known better.

Notes and 71 references. 
63. Weimer, Donna S. 1990. A rhetorical analysis of a scientific controversy: Margaret Mead versus Derek Freeman in cultural anthropology. Ph.D. diss., Pennsylvania State University.

Analyses Margaret Mead and Samoa using Burke's method of entitlement, cluster-agon analysis and structure. "Entitlement reveals the primary agon to be between two agents, Mead and Freeman, rather than two sets of evidence. The cluster-agon analysis reveals Freeman's god-term to be 'science'. He associates [Mead's] research with 'depiction', 'error',...'romantic notions', 'ideology', and 'youth'.... The structure reveals that despite the quantity of evidence Freeman adduces to suport his claims, the evidence is fragmented and decontextualized." Concludes that the form of Freeman's refutation is "dissatisfying" and supports claims of anthropologists that their resistance results from an ethnographically problematic text. A final chapter reviews the scholarly response and summarises some of the questions raised.

Bibliography, pp.246-258.

64. Freeman, Derek. 1991. On Franz Boas and the Samoan researches of Margaret Mead. Current Anthropology 32(3): 322-330.

Reiterates his belief that Mead was sent to Samoa by Boas to study the influence of culture and biology on adolescent stress levels, noting Mead's many published statements to this effect and Murray's reliance on a truncated version of Boas' letter to Mead outlining her research agenda. Defends his characterisation of Boas and other anthropologists as a group in their professional collaboration and shared convictions about culture as the most important determinant of human behaviour. Acknowledges published reservations and skepticism from Lowie and others but contends none of it questioned her extreme environmentalist conclusions, nor did it prevent Coming of age from attaining classic status with the educated public, becoming a set text for tens of thousands of students and having its conclusions uncritically incorporated into anthropological textbooks, encyclopedias and other literature. Lists scholars accepting and repeating Mead's assertions and asserts the bulk of them had doctorates from American universities.

Notes and $130+$ references. 
65. Murray, Stephen O. 1991. On Boasians and Margaret Mead: Reply to Freeman.

Current Anthropology 32(4): 448-452.

Objects to Freeman's representation of the history of anthropology and accuses him of further selective quotation. Stresses Lowie's critical review of Coming of age (q.v.) and less than favourable reaction to some of her later books by Sapir and others. Accuses Freeman again of overrating the importance of Mead's research and findings to Boasian cultural determinism, which was already generally accepted. Reports that only 11 of 27 pre-1983 anthropological textbooks for students incorporate Mead's conclusions about Samoan sexuality. Contends that Mead's global characterisations of the ethos of Samoan culture are the antithesis of the hypercautious particularism of Boasian ethnography. Agrees Mead spent little time in Samoa studying adolescents, that she followed her own agenda and her conclusions were hastily researched and erroneous, but suggests this is because she paid too little attention to her ostensible mentor, not too much. Concludes that it is a legitimate scientific enterprise to challenge Mead's conclusions but not to give the impression that leading Boasians accepted and incoporated them.

Notes and 46 references. 
66. Freeman, Derek. 1991. There's tricks i' th' world: An historical analysis of the Samoan researches of Margaret Mead. Visual Anthropology Review 7(1): 103-128.

Considers the genesis and context of Mead's Samoan fieldwork using published material and unpublished letters and reports from Mead, Boas and Benedict. Comments on Mead's probable preconceptions about Polynesian promiscuity. Gives a detailed account of events over the 9 months of Mead's sojourn in Samoa. Suggests that Mead spent most of her time engaged in general ethnographical research at the expense of her prescribed study of adolescence. Describes the relationship betweeen Mead and Fa'apua'a Fa'amu and the circumstances which the author believes led to an excessive reliance on Fa'apua'a and a second informant. Speculates on the conjunction of factors which led to the anthropologist's willing acceptance of the stories she was told. Concludes with a savage attack on a review by Adam Kuper $^{5}$ of Frank Heimans' film about the controversy ${ }^{6}$.

References not noted. 
67. Cote, James E. 1992. Was Mead wrong about coming of age in Samoa?: An analysis of the Mead/Freeman controversy for scholars of adolescence and human development. Journal of Youth and Adolescence 21(5): 499-527.

Condenses Mead's reasons for the absence of adolescent difficulties in Samoa to the homogeneity of Samoan culture and the casual nature of Samoan culture. Emphasizes the isolation and smallness of Ta'u in 1925. Outlines Mead's own defence of her research from the introductory material to later editions of Coming or age and The social organization of Mamu' $a$ - the "temporary felicitous relaxation" and "little Margaret among the children" theses. Postulates a complex, multifaceted and flexible culture defying easy definition. Accuses Mead of inappropriate generalisation in chapters written at her publisher's request. Defends Mead's understanding of the role of biological factors and quotes recent research proving the minor role played by such factors in explaining variance in adolescent behaviour. Attacks Freeman's characterisation of Mead's downward deviants as delinquents and his misuse of official statistics on juvenile crime. Blames Western influences for Samoan crime rates. Quotes Ala'ilima and Holmes in support of Mead. Concludes with qualified support for the accuracy of Mead's observations but criticism for her overgeneralisation and unsubstantiated speculation. Notes Samoan resentment of Freeman's negative portrayal and Christian Samoan resentment of Mead's claims about promiscuity.

93 references. 
68. Freeman, Derek. 1992. Paradigms in collision: The far-reaching controversy over the Samoan researches of Margaret Mead and its significance for the human sciences. Canberra: Australian National University.

First given as a public lecture at A.N.U. in 1991. Freeman records his conviction that the scientific paradigm that "all human behaviour is the result of social conditioning" is giving way to a new recognition of the importance of a phylogenetically-given primate nature. Represents the vocal and ad hominem opposition of anthropologists to his refutation of Mead's findings as typical of the persistence of outmoded dogma in scientific enquiry and asserts that the evidence of Fa'apua'a Fa'amu regarding her fibs to Mead in 1926 places his contentions beyond doubt. Briefly discusses developments in the fields of DNA analysis of evolutionary divergence, ethology and primatology, noting discoveries of genetic origins of diseases with behavioural components and research on monozygotic twins. Asserts the unity of humankind and its close relationship with certain primates, notes the existence of numerous universal factors in human culture and behaviour and posits a phylogenetically-given human nature coexisting with cultural institutions which have developed from the exercise of the human faculty of choice.

$24 \mathrm{pp}$

69. Marshall, Mac. 1993. The Wizard of Oz meets the wicked witch of the East: Freeman, Mead and ethnographic authority. American Ethnologist 20(3): 604-617.

Analyses Freeman's rhetoric and lexical devices in chapters 2 and 3 of Margaret Mead and Samoa and finds that Mead and her work are overwhelmingly described in negative terms, other researchers in neutral terms and Freeman in positive terms. Gives frequencies for various words. Suggests Freeman has harmed his cause with rhetorical overkill. Notes and 34 references. 
70. Cote, James E. 1994. Adolescent storm and stress: An evaluation of the Mead-Freeman controversy. Hillsdale, N.J.:

Lawrence Erlbaum.

Attacks Freeman and defends Mead's thesis of Samoan society (or at least Ta'uan society in 1926) as the "negative instance" of a culture without adolescent stress. Accuses Freeman of misrepresenting the views of cultural determinists such as Mead and Boas but tends to present Freeman's own position as that of a narrow biological determinist ignoring arguments based on cross-cultural constants and universal human biological imperatives. Refutes Freeman's major accusations point by point, including $\mathrm{Fa}^{\prime}$ apua $\mathrm{Fa}^{\prime}$ amu's statements that she and her friends deliberately misled Mead. Argues that Mead's Ta'u of 1926 was unique in its isolation and that the lifestyles described by Mead reflected a traditional and superior, non-Christian past. Contends that Freeman's perspective as a male and a confidant of chiefs cut off any access to the experiences and views of young women. Paints a picture of Freeman as too close to the society he writes about and concerned, as a man and a Samoan (honorary) matai with friends in matai circles to uphold an idealised picture of Samoan society. Discusses early accounts of Samoa and postulates that sexual practices were very different in the pre-contact period and that missionary influence has imposed "Victorian" values conducive to wage-labour and capital accumulation. Examines the current position of Samoan youth in the light of statistics on suicide and criminal offending and concludes that Western influences have led to cultural disenfranchisement and the eradication of a semi-autonomous sexuality. The author, a sociologist, has no personal knowledge of Samoa but has made an extensive study of the literature.

xiv, 186pp. Bibliography and indexes. 
71. Grant, Nicole J. 1995. From Margaret Mead's field notes: What counted as "sex" in Samoa? American Anthropologist 97(4): 678-682.

Suggests that female autonomy and power influenced the social organisation of what counted as "sex" in traditional Samoa, with penetrative intercourse being proscribed, but manual and oral sexual practices being freely engaged in outside marriage. Adept lovers were expert at having sex without the risk of pregnancy and this type of sex was more conducive to female pleasure than intercourse - indeed virtually assured it. Western influences gradually introduced a new cultural construction of sexuality. Mead was describing a transitional period in Ta'u in 1926. Uses several excerpts from Mead's field notes to support her hypothesis. Suggests retraction of her original oral testimony by Fa'apua'a Fa'amu must be viewed in the context of social change in this area. .

11 references. 
72. Orans, Martin. 1996. Not even wrong: Margaret Mead, Derek Freeman and the Samoans. Novato, Calif:: Chandler and Sharp.

Compares Mead's field notes and correspondence with the published version of Coming of age and concludes that she had been able to form a reasonably accurate picture of Samoan culture and sexuality. However, she then selectively used the information she had gathered to argue a case for cultural determinism and a more permissive sexual code, when the data she had collected would have equally supported the opposite case. Claims her fieldwork was sloppy and her enquiry could not have provided the evidence needed to prove her thesis - thus "her work may properly be dammed with the harshest scientific criticism of all, that it is "not even wrong"' (p.155).

Explores reasons for the enthusiastic and uncritical reception the book received from scholars and the general public including his own use of it as a set reading for his students. Criticises the failure of cultural anthropology to accept the need for a positivist scientific approach.

Describes Mead's understanding of three factors restricting adolescent sexual freedom in Samoa - noble birth, age and residence in the pastor's house, claiming that the first of these applied to a much larger proportion of the population than is generally recognised. Notes Mead's view that earlier generations had lived under a much stricter regime. Discusses evidence from Mead, Freeman and Holmes about Christianisation and internalisation of a sense of sin. Considers the "temporary felicitous relaxation" and the "little Margaret among the children" explanations, but concludes. from a listing of all the clearly positive and negative statements in Coming of age in Samoa (which shows the negative outweigh the positive nearly two to one), that such hypotheses are unnecessary. Accuses Mead of leaving out certain incidents recorded in her fieldnotes, such as the rape of an eight year-old girl and the immensely destructive hurricane which led to a "famine in native foods" by the time of her departure.

Examines Mead's field writings for evidence of her command of Samoan and her sources of information. Finds inconsistencies in her population statistics and evidence that two of her chief informants on sex were a young man and a European school teacher and that much of her data was gathered in English. Suggests her sources for her figures on such matters as sexual experience are dubious and amount to little more than gossip in some cases. 
assertions of chastity as the norm for taupou, that none of the information in the field notes is attributed to Fa'amu and her letters to Mead contain nothing of ethnographical interest, that Mead records the trip to Ofu and Olosega in a news bulletin letter but mentions nothing about receiving important new information, and that her letters to Boas show no change in her attitudes as a result. Accuses Freeman of leaving out a critical phrase from one of these letters - which ruins Freeman's interpretation of too much ethnography and too little focus on the question of adolescent stress.

The author spent 18 months doing anthropological fieldwork in Samoa in the 1970s and 1980s. viii, 190pp. Bibliography, pp.179-182 and index.

73. Shankman, Paul. 1996. The history of Samoan sexual conduct and the Mead-Freeman controversy. American Anthropologist 98(3): 555-567.

Reviews Freeman's history of sexuality in Samoa in the light of contemporary accounts from missionary times to the 1950 s and concludes that he is guilty of selective quotation to buttress his case and that the picture given by Mead is probably quite factual. Distinguishes between ideology and behaviour, noting the double standard evident in male pride in seduction of virgins. Compares figures for Samoa given by Mead and Freeman with similar figures for the United States 1920-1970 and finds more pre-marital chastity in the United States. Argues the traditional role for taupou in cementing political alliances was weakened by the abolition of polygamy and that chastity requirements did not apply to other women. Suggests that missionary focus on reforming sexual relations implies a perception of Samoan culture as anything but puritanical. Quotes from Williams, Kramer, Keesing, Calkins, Michener and Stanner to prove that Samoan society has always been less puritanical than portrayed by Freeman. In particular, suggests widespread, and parent-sanctioned liaisons with US troops in World War II are hard to reconcile with Freeman's picture of Samoan society. Notes Freeman was in Samoa 1940-1943 and expresses surprise at the lack of any mention of this period in his writings. Rebuts Freeman's dismissal of the idea of substituting chicken blood in the defloration ceremony, quoting Kramer to the effect that the practice was widespread. Accuses Freeman throughout of omitting passages which would contradict his thesis.

Notes and $50+$ references. 
Margaret Mead and Derek Freeman: Bibliography of a controversy

74. Williamson, David. 1996. Heretic: Based on the life of Derek Freeman. Ringwood, Vict.: Penguin.

A play in two acts, based around the lives of Derek Freeman and Margaret Mead. Dramatises many of the salient points brought out in the course of the controversy. Characters include young and old versions of Derek Freeman and Margaret Mead, Ruth Benedict and Franz Boas, Fa'apua'a Fa'amu, Fofoa (her friend), and Aviata, Margaret Mead's Samoan lover, and Derek Freeman's wife, Monica. A five page introduction outlines Freeman's interactionist paradigm. $97 \mathrm{pp}$.

16261 words 


\section{Index}

acculturation in Samoa 17, 24, 25, 38, 47, 57; dismissed as explanation 36

Adolescent storm and stress: An evaluation of the Mead-Freeman controversy 70

adolescent behaviour, influence of biological factors on 67

adolescents (United States) 1, 17, 21

adoption in Samoa 5; see also residential flexibility (adolescent)

adultery in Samoa 1, 5, 9, 12, 20, 32, 53

adultery in the U.S.A. 43

aga and amio $11,28,32$

aggression in Samoa 11, 12, 28, 39, 48, 57

Ala'ilima, Fay 29

reply by Freeman 32

American Anthropologist 2, 4, 6, 17-20, 38, 39, 41, 44, 45, 48, 53, 59, 60, 71, 73

American Ethnologist 69

The American Scholar 46

anthropological restudies see restudies (anthropology)

anthropologists' reactions to the controversy $33,43,46,51$

anthropology

applied/advocacy 56; biases in 53; fieldwork see fieldwork in anthropology; indigenous views of 54; professional ethics 61; restudies see restudies (anthropology); Samoan views of see Samoan reactions to the controversy

Appell, G.N. 33,52

Australian and New Zealand Journal of Sociology 43

Bali 7

\section{Bargatzky, Thomas 51}

Barnouw, Victor 13

behaviorism, influence on Mead 57

Benedict, Ruth 7, 12,13 see also configurationalism and culture and personality theory

bibliography of the controversy 23

biological determinism, kinds of 18

Boas, Franz 13, 14, 20, 21, 28, 30, 32, 43, 62

influence on Mead 12,62, 64, 65, 66

Boasian school 12, 62, 64, 65

Bock, Philip K. 14

Brady, Ivan, (ed.) 17-20

brother/sister relationships in Samoa 26

Canberra Anthropology 10, 21-28

Caton, Hiram 34, 61

Central issues in anthropology 54, 56

Children - punishment 9, 12,57

Choice and morality in anthropological perspective: Essays in honour of Derek Freeman 52

Christianity in Samoa 47, 56, 72

colonialism 47,56

Coming of age in Samoa: A study of adolescence and sex in primitive societies 1 discrepancies between sections 2, 18, 53; reception and influence 12, 22, 29, reviewed 2

Coming of age in Samoa: A psychological study of primitive youth for Western civilization see Coming of age in Samoa: A study of adolescence and sex in primitive societies

competition for rank and status in Samoa 36, 53, 57

configurationalism $19,26,27,33$, influence on Mead 62

conflict, intergroup (in Samoa) 57 see also aggression

Cote, James E. 67,70

crime in Samoa 12,14, 67

cultural determinism $12,13,18,20,21,26,28,30,34,45,43,61$

cultural maximalism 43

cultural relativism 10,2128

culture and personality theory 54

culture (anthropology) 46, 61

culture, evolution of 10,35

Current anthropology 62, 64, 65

'Derek Freeman: Notes towards an intellectual autobiography' 52

diffuseness of afffection in Samoa 19, 28, 37 
double socialisation in Samoa 11, 19, 28

The Eastern Anthropologist 33

Ember, Melvin 38

Ethos 35

reply by Freeman 39

eugenics movement $12,20,46,54$

evolution of culture see culture, evolution of

Fa'amu, Fa'apua'a 8, 12,

'Fact and context in ethnography: The Samoa controversy' 21-27, 28

falsificationism see Popperian refutation

family relationships in Samoa 39, 57

Feinberg, Richard 53

feminist interpretations $36,56,71$

Feminist Studies 36

fieldwork in anthropology 25

in Mexico 15; in Ireland 37

Foerstel, Lenora 54

Freeman, Derek 10, 12, 28, 32, 39, 42, 45, 48, 49, 59, 60, 64, 66, 68

biography $52,61,74$; correspondence with Holmes 61 ; his contrarian bias 18, 24 ; his delay in publishing 21, 25 his fieldwork 21 ; his positivist approach 40 ; his rhetoric critiqued 63,69 ; his use of quotations $17,30,32,62$; his use of statistics $14,24,25,30,32,38,43,67$

on virginity $17,20,44$

Freudian psychology, influence on Mead 13, 54, 57

Grant, Nicole J. 71

Hammond, Joyce D. 41 reply by Freeman 42

Heretic: Based on the life of Derek Freeman 74

Holmes, Lowell D. 5, 21, 47

attacked by Freeman 28, 59; correspondence with Freeman 28, 61; his fieldwork 47;

his knowledge of Samoan language 5, 59;

his relations with Mead 21

Hooper, Antony 40

Human Organization 37

ideal/actual in human behaviour $24,32,41,42,73$

identity (in Samoa) 11

'Inductivism and the test of truth' 28

interactionism $10,12,27,30,32,33,37,68$; defined 52

Jarvie, I.C. 22

Journal of Anthropological Research 14

The Journal of Psychoanalytic Anthropology 13

Journal of the Polynesian Society 5, 49, 50

Journal of Youth and Adolescence 67

Juan, S. 43

Kroeber, Alfred 12

Laing, Patricia Kinloch 50

Leacock, Eleanor 56

Letters from the field 1925-1975 8

Levy, Robert I. 35

Lowie, Robert H. 2,

Madan, T.N. 52

Mageo, Jeannette Marie 57

Malinowsky, Bronislaw 20;28 see also Trobriand Islands

Manu'a - ethnography 3

Manus 18

Margaret Mead and Samoa - reviews 12, 14, 29, 30, 31, 40

Margaret Mead and the heretic see Margaret Mead and Samoa

Marshall, Mac 69

McDowell, Nancy 30

reply by Freeman 32

Mead, Margaret $1,3,6,7$,

as a generator of myth 46 ; allegations of duping $18,31,32,59,60,66,68$, denied 70,72 ; autobiography 7 ;

her field correspondence 8,72 ; her fieldwork $7,8,12,15,18,22,54,72$; her influence on anthropology 64,65 ; her knowledge of Samoan language 25, 72; her informants 72; her meeting with Freeman in 1964 15, 28

her political and social achievements 37 ; on cultural relativism 43 


\section{Meleisea, Malama 24}

criticised by Freeman 28

moetotolo 5, 9, 14, 16, 24, 32, 37,

Murray, Stephen O. 62,65

reply by Freeman 64

myth, role of 46

Nardi, Bonnie A. 36

nature and nurture see cultural determinism

Not even wrong: Margaret Mead, Derek Freeman and the Samoans 72

nuclear family in Samoa 37; see also diffuseness of affection in Samoa

Oceania 40

\section{Orans, Martin 72}

Pacific Islands monthly 16

Pacific Studies 29, 30, 31, 32, 51, 57, 58

Paradigms in collision: The far-reaching controversy over the Samoan researches of Margaret Mead and its significance for the human sciences 68

participant observation 8; see also subjectivity in anthropology

Patience, Allan 44

reply by Freeman 45

Paxman, David B. 58

perspectives, different see subjectivity in anthropology

political implications $37,38,56$

Popperian refutation $19,26,28,35,37,39,44,45,46,58$

psychometric studies see Samoans, psychometric studies of

Quadrant 34

Quest for the real Samoa: The Mead/Freeman controversy \& beyond 47

critiqued by Freeman 48, 49; reviewed 51

rape in Samoa 9, 25, 32, 36, 39, 48, 59 urban-rural rates compared 28

Rappaport, Roy A. 46

residential flexibility (adolescent) 9, 19, 24,

respect language in Samoa 30, 32; see also interactionism

restudies (anthropology) 17, 22

Reviews in Anthropology 15

Reyman, Jonathan E. 41

reply by Freeman 42

'A rhetorical analysis of a scientific controversy: Margaret Mead versus Derek Freeman in cultural anthropology' 63

Romanucci-Ross, Lola 15

Sala'ilua: A Samoan mystery 11

critiqued by Freeman 28, 32

Samoa - cultural uniformity 45

inter-village differences 38

urban-rural differences 39,47

Samoa - ethnography 9,11,12,61 see also Ta'u -ethnography and Manu'a - ethnography

Samoan concepts and perceptions 11

Samoan reactions to the controversy $16,29,35,31,39,47,67$

Samoan sexuality $1,12,26,32$; feminist view 36 ; history of $70,71,73$; obtaining information about 25,47

The Samoa reader: Anthropologists take stock 61

Samoans, psychometric studies $1,17,47$

Sapir Edward 65

Scheper-Hughes, Nancy 37

Schoeffel, Penelope 9, 24

criticised by Freeman, 28

Schwartz, Theodore 18

sexual activity, premarital (in Samoa) $12,13,14,20,24,26,28,72,73$

feminist view 36

sexual activity, premarital (in U.S.A.) 41, 73

Shankman, Paul 25, 73

criticised by Freeman 28

Shore, Bradd 11, 19, 26

Smith, Joseph Wayne 44 reply by Freeman 45

social change see acculturalisation

social control 11

Social organization of Manua 3

South Seas paradise 16, 29, 58 
'Speaking in the name of the real: Freeman and Mead on Samoa' 17-20

'Special section: Speaking in the name of the real' $17-20$

'Special volume: Fact and context in ethnography: The Samoa controversy' 21-27, 28

Strathern, Marilyn 27

criticised by Freeman 28

subjectivity in anthropology $24,27,33,35,37,50,58,70$

suicide in Samoa 9, 25, 47, 70

Ta'u - ethnography of 1,5 ; uniqueness and isolation $20,21,51,70$, dismissed as factor $26,39,45$

Ta'u: Stability and change in a Samoan village 5

reviewed by Mead 6

taupou $1,5,20,53$

Tchambuli 54

Trobriand Islands 20; see also Malinowski, Bronislaw

Visual Anthropology Review 66

Weimer, Donna S. 63

Weiner, Annette 20

Wendt, Albert 16

Wendt, Tuaopepe Felix S. 31

reply by Freeman 32

Williamson, David 74

Winston, Ellen 4, 13

women, status of (in Samoa) 9, 16

Young, R.E. 43 